\title{
The Advantage of Incumbents in Coalitional Bargaining*
}

\author{
Jaakko Meriläinen $^{\dagger} \quad$ Janne Tukiainen ${ }^{\ddagger}$
}

October 21, 2021

${ }^{*}$ We thank Jon H. Fiva, Fabio Franchino, Carlo Prato, and Federica Izzo for useful comments and discussions. Seminar and conference participants at Helsinki GSE, Online Political Economy Seminar Series, and EPSA provided helpful feedback.

${ }^{\dagger}$ Corresponding author. Centro de Investigación Económica and Department of Economics, ITAM, Camino Santa Teresa 930, Héroes de Padierna, Magdalena Contreras, 10700 Ciudad de México, Mexico. Email: jaakko.merilainen@itam.mx. Tel: +525582327639.

${ }^{\ddagger}$ Department of Economics, Turku School of Economics, Rehtorinpellonkatu 3, FI-20014 University of Turku; VATT Institute for Economic Research, Arkadiankatu 7, Helsinki FI-00101. Email: janne.tukiainen@utu.fi. Tel: +358295519451. 


\begin{abstract}
Political parties frequently form coalitions with each other to pursue office or policy payoffs. Contrary to a prominent argument, the distribution of rents within the coalition does not always reflect the relative sizes of the coalition members. We propose that this is at least partially due to an incumbency advantage in coalitional bargaining. To evaluate this argument empirically, we construct a data set of candidates, parties, and members of the executive in Finnish local governments. We first use a regression discontinuity design to document a personal incumbency advantage in nominations to executive municipal boards. We then show that an incumbency premium is present also at the party level. Using an instrumental variable strategy that hinges on within-party close elections between incumbents and non-incumbents, we find that, ceteris paribus, having more re-elected incumbents increases party's seat share in the executive.
\end{abstract}

Keywords: coalitional bargaining, coalitions, government formation, incumbency advantage, local government, multi-party system

Word count: 9,973 
Political parties frequently form coalitions with each other in pursuit of office and policy payoffs. One aspect of this process that has puzzled scholars for decades is how rents are distributed as a result of bargaining. A prominent example is government formation in parliamentary systems, where the executive branch of government is typically selected by a group of elected representatives. In line with Gamson's prominent hypothesis (Gamson 1961), empirical studies have documented a strong association between parties contribution to the governing coalition and the share of executive leadership positions that they get (Browne and Franklin 1973; Warwick and Druckman 2001; Mershon 2001; Bäck, Debus, and Dumont 2011). ${ }^{1}$ Yet, parties' representation in the executive branch of government rarely is perfectly proportional to their electoral performance (Browne and Frendreis 1980; Ansolabehere et al. 2005; Falcó-Gimeno and Indridason 2013).

Formal theories of bargaining applied to political coalition formation often attribute this to a formateur advantage (see, e.g., Baron and Ferejohn 1989): the party that gets to try forming a coalition first gets the largest payoff, no matter how large its coalition partners are. Both experimental and observational studies have tested this claim but with mixed results. Ansolabehere et al. (2005) find evidence of a formateur advantage in government formation, but several other studies argue that the advantage appears to be smaller than implied by conventional bargaining models, or even non-existent (Fréchette, Kagel, and Lehrer 2003; Warwick and Druckman 2006; Laver, de Marchi, and Mutlu 2011). This leaves us with a puzzle. What then could explain imbalances in the distribution of political power?

We propose that there is an incumbency advantage in coalitional bargaining, i.e., incumbents and parties that have more incumbent representatives fare better in the bargaining process than otherwise similar non-incumbents and parties with less incumbents. This advantage could stem from various sources. First, there can be informal norms within and between political parties that benefit incumbents. Second, incumbency can be a quality that benefits politicians themselves and the parties they represent in the bargaining process through factors such as established networks or

\footnotetext{
${ }^{1}$ Laver (1998) notes that this empirical regularity known as Gamson's law is “[...] one of the highest nontrivial R-squared figures in political science."
} 
trust. $^{2}$ To the best of our knowledge, this argument is novel, although incumbents are well known to enjoy various other advantages in the political arena. For instance, in many settings, they attract more campaign finance, get more media attention, and are more likely to get re-elected in future elections (Gelman and King 1990; Levitt and Wolfram 1997; Fouirnaies and Hall 2014).

To empirically assess the role of incumbency in coalition formation, we construct a data set of candidates, parties, and their coalitional bargaining outcomes in local governments in Finland. Just like governance in any parliamentary system, Finnish municipal governments are composed of a legislative and an executive branch (the local council and the municipal board, respectively), and the latter is nominated by elected local councilors. We study how incumbency influences nominations to the municipal board both at the individual and the party level.

At the individual level, we observe that re-elected incumbents are almost twice as likely to be nominated to the municipal executive boards than non-incumbents. However, we do not find that incumbency would increase the probability of a politician becoming the board chairman. We are able to estimate the impact of incumbency on political promotions causally using a regression discontinuity design that hinges on close elections that occur within party lists due to the Finnish open-list system (Hyytinen et al. 2018b; Hyytinen et al. 2018a). This finding adds a new insight to the extensive literature on incumbency effects. However, a crucial question remains open: does incumbency only matter how important political positions are distributed within parties, or does incumbent representation also shape the distribution of political power between parties?

The main part of our analysis investigates the effects of incumbent representation at the party level. ${ }^{3}$ Due to institutional features that we will return to later in the paper, all parties that gain

${ }^{2}$ Incumbency is commonly used as a marker of politician quality (see, e.g., Jacobson 1989; Ansolabehere, Snyder, and Stewart 2001), and prior research has also demonstrated that incumbents can make more efficient policy-makers (Freier and Thomasius 2016; Meriläinen 2020).

${ }^{3}$ In related work, Martin and Stevenson (2010) and Glasgow, Golder, and Golder (2011) document that incumbent parties have an advantage in government formation. We take an intraparty perspective instead of comparing incumbent and non-incumbent parties. 
representation in the local council are typically represented in the municipal board as well. Hence, we do not study which parties become part of the ruling coalition (the extensive margin) but rather parties' seat shares in the executive (the intensive margin). Parties have some leeway in allocating the seats in the executive for two reasons. First, the seat distribution does not need to be approved unanimously. Second, there are less seats in the executive than in the council which creates disproportionality that the parties must resolve somehow. These notions are apparent in Figure 1: there is a strong relationship between parties council seat share or voting power and the share of board seats they get, but many parties exceed or fall short of the board seat share we would expect them to obtain based on the political power that they posses. ${ }^{4}$

Our data reveal that incumbents boost the bargaining outcomes of the parties that they represent. For example, we find that a one standard deviation increase in the incumbent council seat share translates into a "bargaining premium"-a benefit independent of the political power of a party —of more than half a seat more in a median-sized executive board. This premium is large enough that it can explain a considerable part of the discrepancies that we see in Figure 1. Moreover, we document that having more re-elected incumbents increases the probability that a party becomes the government formateur, proxied by getting to nominate the head of the local government (chairman of the municipal board). To hold all other factors fixed and to identify these effects causally, we follow the approach pioneered by Hyytinen et al. (2018a) and construct an instrumental variable that exploits within-party close elections between incumbents and non-incumbents.

Analyzing effect heterogeneity with respect to different institutional factors and party characteristics provides us with additional insights on when and why an incumbency advantage

\footnotetext{
${ }^{4}$ We measure the political power of a party with their seat share in the municipal council and by constructing a voting power index following Shapley and Shubik (1954). The Shapley-Shubik index is defined as the fraction of possible votes in which the party is decisive for the outcome of the vote. It takes values between zero (a party cannot affect the outcome of the vote) and one (a party has an absolute majority).
} 

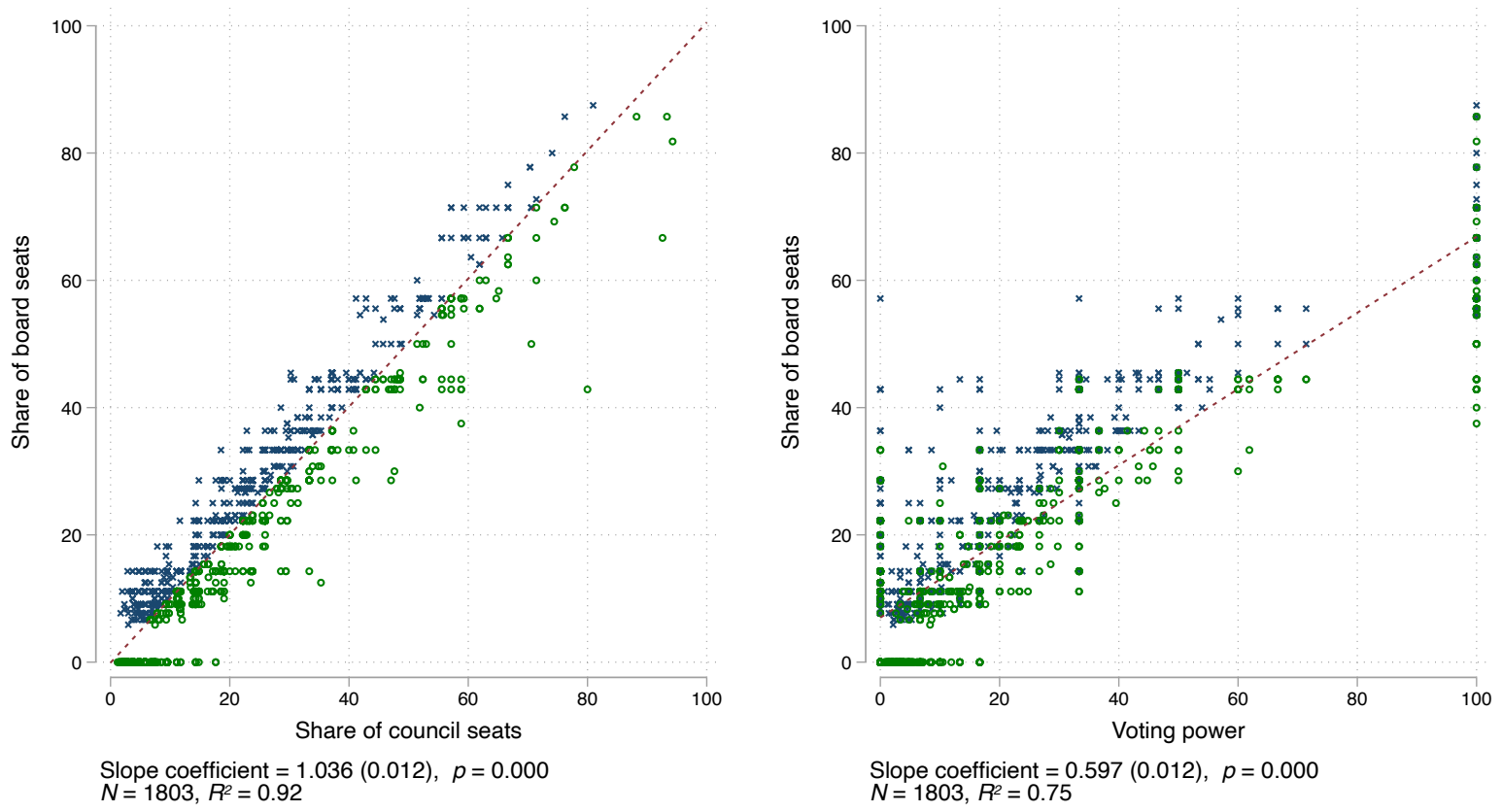

Figure 1. Parties' political power in the municipal council and the municipal board.

Notes: Each cross (circle) marks a party that holds a greater (smaller) share of board seats than council seats. We measure voting power following Shapley and Shubik (1954). We also show a linear fit and report the corresponding slope coefficient alongside with its standard error clustered at the municipality level.

arises. We show that having more re-elected incumbents is particularly useful to political parties when they are in a disadvantaged bargaining position and when the bargaining environment is more complex, i.e., when the local government is more fragmented. These findings imply that incumbents can make the bargaining process less costly.

Our findings speak to the prior literature on the formation of political coalitions and governments. Two fundamental questions in this literature are who becomes part of the governing coalition and what explains the portfolio shares that different coalition members acquire (see Laver 1998 for a review). An important strand of scholarship has carefully documented how diverse institutional features and party-level characteristics such as party size and ideology influence coalition membership and formateur selection (Diermeier and Merlo 2004; Bäck and Dumont 2008; Glasgow, Golder, and Golder 2011; Fujiwara and Sanz 2019). However, earlier literature has left the importance of parties internal composition untouched. Furthermore, scholars 
have been predominantly focused on coalition formation in national politics, even if local governments are a key building block of many polities (Stoker 1991).

What is more, our empirical case closely resembles the selection of parliamentary committees that Strøm (1998) argues are “[...] among the most important features of legislative organisation in contemporary democracies." Prior scholarship has already recognized the importance of senioritybased nomination norms in such settings (McKelvey and Riezman 1992; Epstein et al. 1997). The framework that we propose in this paper could be extended to study representation in committees.

\section{Institutional Background}

We study the formation of the executive in local governments in Finland. ${ }^{5}$ This section provides an overview of the institutional background.

\section{Finnish Local Politics}

The municipalities are led by elected local councils in which the decisions are taken by a simple majority of the council members. The number of council seats is a step-wise function of the population, and it varies between 13 and 85 . A median council has 27 seats. Local councils can set up committees to deal with different functions such as social and health services, education or urban planning. Seats in these organs are divided proportionally between the parties following the election result, and typically every elected councilor is assigned to at least one committee. Thus, elected politicians have several channels to influence policy-making.

\footnotetext{
${ }^{5}$ Local governments have an important role in the Finnish system. On average, they spent more than 5,000 euros per capita per year during the period of our data (2000-2012). The majority of local expenditures is used to take care of statutory responsibilities such as health care. To cover their expenditures, the municipalities are allowed to collect income and property taxes. They also receive a share of corporate taxes and fiscal grants from the central government.
} 
Municipal elections are organized every fourth year, and during the period of our investigation, a new local council started its tenure at the beginning of January. The electoral system uses proportional representation with (pure) open lists. This means that a voter has to casts her ballot for a single individual candidate and cannot directly vote for just a party. ${ }^{6}$ Each party's vote count is simply the sum of personal votes over all the party's candidates. The seats in the council are allocated using the D'Hondt method. Therefore, the seat allocation between political parties depends on the vote shares of the parties and the seat allocation within the parties depends on the personal votes. ${ }^{7}$

The municipal elections held between 2000 and 2012 were dominated by three large parties from the political left, center, and right: the Social Democratic Party, the Center Party, and the National Coalition Party, respectively. Other parties that hold seats in both municipal councils and the National Parliament are the Left Alliance, Green Party, Finns Party, Swedish People's Party, and Christian Democrats. There are several smaller parties, and many municipalities have local, independent or one-agenda political groups.

\section{Municipal Executive Boards}

Every local council selects a municipal executive board that can be considered the government cabinet of a municipality. Municipal boards are responsible for preparing the local decision-making. The municipal executive board is headed by a chairman whose job is

\footnotetext{
${ }^{6}$ Before an election and at polling stations, voters have access to a candidate list that shows different parties and lists the names of their candidates, sometimes alongside with other information such as candidates' occupations. Parties' order on the list is chosen randomly, and candidates are almost always ordered alphabetically within the party lists.

${ }^{7}$ Meriläinen and Tukiainen (2018) show that the personal votes have a role beyond determining the election result: a candidate's within-party rank matters for his or her chances of acquiring a political promotion.
} 
considered to be the most important position in local politics (Meriläinen and Tukiainen 2018). It is roughly comparable to the position of a mayor in many other political systems. ${ }^{8}$

When an election is over, parties bargain with each other on who gets to nominate the board chairperson and how to distribute the seats in the municipal executive board and other municipal decision-making organs. ${ }^{9}$ Size of the municipal board is typically set by the previous local council, and it strongly correlates with council and municipality size. The number of board seats varies between 6 and 17, and the median board has 9 seats. As we already demonstrated in Figure 1, representation in the executive board proportionally reflects the party composition of the local council. However, given the size difference, there cannot be an exact mapping from council to board seats.

The local council members must approve the nominations in a vote unless the council unanimously approves the proposed nominations. The council usually follows a "gentlemen's agreement" and respects both the between-party bargaining result and the within-party choices. If not and an election is needed, the council elects board members either in a majority election one representative at a time, or in a vote that follows the principle of (closed-list) proportional representation. Proportional representation is used if it is requested by a sufficient number of

${ }^{8}$ Other positions in the municipal board are essentially equally valuable, differentiating our case from many national contexts where different cabinet positions may be of a different importance (Warwick and Druckman 2001), or where the relative salience of cabinet positions to individual parties may matter (Ecker, Meyer, and Müller 2015). On the one hand, one may see this as an advantage that keeps the empirical case simple. On the other hand, it may limit the generalizability of our results to more professional contexts such as national politics.

${ }^{9}$ Parties typically choose a group of 1-3 politicians to spearhead the bargaining process. Many parties instruct their local branches to have politically experienced representatives involved. See, for instance, the guidelines provided by the Green Party at https://www.vihreat.fi/files/ liitto/Luottamuspaikkaneuvottelijanopas_2014.pdf (accessed September 8, 2020). 
council members. ${ }^{10}$ Therefore, there is an institutional constraint that imposes a certain degree of fairness between parties in all municipalities, even when an election is not used to select the board members. This institutional feature also hinders the largest party—even if it had more than half of the council seats-from dominating the bargaining process.

Board members do not have to be elected local councilors (although they mostly are). Only civil servants who are in executive positions cannot be selected. Furthermore, municipal employees cannot constitute more than half of the board members.

\section{Theoretical Considerations}

This section discusses the potential role of incumbents in the formation of municipal boards. We first lay out two main predictions that are empirically testable. The latter part of this section discusses auxiliary predictions regarding the heterogeneous nature of the hypothesized relationship between incumbent representation and payoffs from the bargaining process.

\section{Main Hypotheses}

Our main proposition is that there is an incumbency advantage in bargaining for seats in the municipal board. In other words, incumbents and parties that have more incumbent representatives fare better in the bargaining process than otherwise similar non-incumbents and parties with less incumbents.

\footnotetext{
${ }^{10}$ More precisely, if a council with $N$ seats is electing $M$ representatives for the executive board, at least $\lceil N /(M+1)\rceil$ must demand using proportional representation for electing the executive board. See, for instance, the guidelines provided by the Finnish Association of Local Authorities at https://www.kuntaliitto.fi/yleiskirjeet/ 2012/kunnanhallituksen-lautakuntien-ja-muiden-toimielinten-valinnat (accessed September 17, 2020).
} 
At the individual level, an advantage could arise from the fact that incumbency is a fundamental politician quality (see, e.g., Jacobson 1989; Ansolabehere, Snyder, and Stewart 2001). This notion manifests itself in diverse ways. For instance, research has demonstrated that incumbents can make more efficient policy-makers (Freier and Thomasius 2016; Meriläinen 2020). We also know that incumbents enjoy other diverse advantages, in particular in electoral contexts: they attract more campaign finance (Fouirnaies and Hall 2014), get more media attention (Levitt and Wolfram 1997), are more likely to get re-elected in future elections (Gelman and King 1990), and so forth. These findings could be a result of incumbents accumulating "political human capital" or building better networks while in office, or other similar factors. These could be relevant attributes also when parties are considering whom to nominate to important political positions.

Furthermore, coalition formation could be steered by informal rules or norms (Fujiwara and Sanz 2019, Cirone, Cox, and Fiva 2020), according to which parties should prioritize incumbents, or their opinions, in the coalition formation process. ${ }^{11}$ This remark is also somewhat connected with the idea of familiarity in government formation (Browne and Rice 1979; Franklin and Mackie 1983). If parties and their incumbent representatives care about the ability of the executive board members to work together, they might prefer the nomination of individuals whom they already know and trust. These considerations lead to our first empirically testable prediction:

Prediction 1. Incumbents are more likely to become members of the municipal board.

But would such a personal incumbency advantage, if it exists, advantage political parties? An important class of political coalition formation theories predicts that the share of coalition portfolios that a party gets depends on the share of seats that a party contributes to the governing coalition (Gamson 1961; Bassi 2013). If this hypothesis-commonly known as Gamson's law-

\footnotetext{
${ }^{11}$ Related theoretical work examines the role of seniority and incumbency in legislatures (see, e.g., McKelvey and Riezman 1992; Muthoo and Shepsle 2014). Eguia and Shepsle (2015) present a legislative bargaining model where the equilibrium agenda protocol disproportionately favors more experienced legislators who get more opportunities for making policy proposals.
} 
is true and the only relevant force at work, then party composition should not matter at all for parties' bargaining outcomes. That is to say, we would expect two equally big parties to get the same share of positions in a municipal board, even if one of the parties would have more incumbent politicians. However, Gamson's law has been subject to considerable empirical scrutiny, and research has recognized that it does not appear to hold in a strict sense (Browne and Frendreis 1980; Ansolabehere et al. 2005; Falcó-Gimeno and Indridason 2013). This opens a window for complementary explanations.

While standard theories of bargaining in politics do not consider a case like ours where all parties get representation in the executive, similar mechanisms can still apply at both the extensive and the intensive margin. Based on such theories, the relationship between parties' bargaining outcomes and the political power that they hold is not straightforward. For example, the legislative bargaining model of Baron and Ferejohn (1989) and other similar models suggest that there is an additional premium for the government formateur. The party that gets to make the first proposition on how to allocate the seats in the executive gets more seats than any other party, no matter how large the other coalition partners are. In this type of set-up, having more incumbent politicians could give a party a larger share of the pie by making a party more likely to become the formateur or a more attractive partner. This could be the case if incumbency makes politicians more capable in governing, for example, due to previously established trust or skills acquired in office, or if parties follow informal seniority norms also in the between-party allocation of political posts. Having more politically experienced incumbents could also boost parties' bargaining power, for example, due to established networks, and thus, increase bargaining outcomes (Ansolabehere et al. 2005).

Of course, when forming governing coalitions, parties might not be seeking merely office but also policy (Baron 1991; Baron 1993; Bassi 2017). If parties care about policy improvements, they might desire to form a coalition with other parties that have more experienced politicians who could be better at governing, and thus promoting common goals, boosting the bargaining prospects of such parties. In our case, such common goals might include outcomes such as 
satisfying the fiscal sustainability criteria that the local governments must follow, avoiding a merger with another municipality, or lobbying the central government for discretionary fiscal grants. Our second empirical prediction thus is:

Prediction 2. Parties with more incumbents are more likely to obtain a larger proportion of seats in the municipal board.

\section{Party Characteristics, Political Context, and the Role of Incumbents}

Beyond the overall role of incumbency, we postulate secondary hypotheses regarding how incumbent representation may interact with various party characteristics and the local political context. We focus on factors that earlier literature has found to be important in government formation: party size and ideology (e.g., Martin and Stevenson 2001; Mattila and Raunio 2004; Bäck, Debus, and Dumont 2011), and complexity of the bargaining environment (e.g., Martin and Vanberg 2003; Golder 2010; Blockmans et al. 2016).

Party Size and Formateur Status. Two important party-level factors that may interact with incumbent representation are party size and formateur status. Thinking about a Baron-Ferejohn-type bargaining framework, incumbents could be particularly beneficial for non-formateur parties if incumbents help them erode some of the formateur's advantage-even if incumbent representation might also help them become the formateur. However, it is not obvious that that incumbent representation would always help political parties in such a set-up. For example, if parties are purely office-seeking and there is an exogenously determined incumbency "bonus", the formateur may be less inclined to include a party with many incumbents to the

proposed coalition, as it would be a more expensive coalition partner. This can happen if, as speculated above, the probability of being recognized as the formateur is a function of party size and composition. Then, larger parties and/or parties with more incumbents that are not the formateur would have a greater continuation value (i.e., the present value of the equilibrium payoff stream) than parties with less seats and/or incumbent representatives. The formateur party 
would have to offer them a larger share of the pie in order to have the proposal accepted, which makes them less desirable associates. In summary, if parties are purely office-seeking, we have the following two predictions:

Prediction 3. Incumbent representation is more beneficial for parties other than the formateur.

Prediction 4. The relationship between incumbent representation in the local council and parties' seat shares in the municipal board is concave.

Party Ideology. It is possible that the advantage depends on the ideological position of a party relative to others. In prior work, researchers have shown that the greater the ideological distance between two parties is, the less likely it is that they become coalition partners (Laver 1998; Martin and Stevenson 2001). Although ideology does not influence whether a party is represented in the municipal board or not in our case, it could still matter for seat distribution at the intensive margin. But how ideological differences could interact with incumbent representation is not clear.

On the one hand, a party might be even more hesitant to form a coalition with parties that have more experienced political personnel, if incumbents are better at advancing partisan policy goals or if incumbents are more extreme than other politicians (see, e.g., Ansolabehere, Snyder, and Stewart 2001). This could steer policy further away from its own goals. On the other hand, incumbent representation could mediate the negative relationship between ideology and bargaining performance. For example, previous experience of working together in the council may reduce distrust stemming from different party ideologies, or incumbents' governing skills may be a substitute for ideology. Ex ante, it is not obvious which of these forces dominates, so we will assess the role of ideology in an exploratory manner in our empirical analysis.

Complexity of the Bargaining Environment. Lastly, incumbent representation may interact not only with other party-level characteristics but also with different institutional factors and features of the party system. Incumbents and their political skills and existing between-party networks could make the bargaining process in itself less costly. Importantly, experienced politicians and 
their networks might come in handy when the bargaining environment is more complex. For instance, coalition researchers have discussed the role of political polarization and government fragmentation as causes of bargaining delays (Martin and Vanberg 2003; Golder 2010; Blockmans et al. 2016). This gives us our last empirical prediction:

Prediction 5. Parties benefit from incumbent representation more when the bargaining environment is more complex.

\section{Data}

We test our hypotheses with a data set that combines information on candidates, electoral results, and post-electoral bargaining. Summary statistics of these data are available in Appendix Table A1. Our election data cover four elections between the years 2000-2012, and they come from the Ministry of Justice. These data include information such as candidates' party affiliation, electoral performance, and previous political experience. In total, the data cover 155,284 candidate-election year observations, out of which over 90,263 are unique individuals. We combine these information with data on chairmen and members of the municipal boards. These data come from the Finnish Association of Local Authorities. The chairman data are available for all the above electoral terms, but we observe other board members only for the 2009-2012 electoral term.

In some of our analyses, we collapse the data to the party level. We focus on parties that acquire at least one seat in the municipal election, and thus, participate in the coalitional bargaining process. Furthermore, we rule out municipalities where one party holds all seats. At most, we use 7,636 (party-electoral term) observations, although the analyses on board members only use 1,803 observations. The average party holds almost one fifth of local council seats and a roughly corresponding share of board seats. We also use the Shapley-Shubik index to capture parties' voting power (Shapley and Shubik 1954). ${ }^{12}$ Our full sample covers 1,124 municipality-election

\footnotetext{
${ }^{12}$ We compute the power indices using vpowerin package in Stata (Ecker 2019).
} 
level observations. In the limited sample for which we observe the municipal board composition, our data cover 332 municipalities.

To understand how incumbent representation might interact with party characteristics and the political environment, we construct a few additional variables. First, we define Ideological distance $_{p m t}$ (for each of party $p$ in municipality $m$ at time $t$ ) as the absolute deviation between their policy position and the seat-share-weighted average policy position of the local council. ${ }^{13}$ Second, we measure Polarization $n_{m t}$ as the sum of seat-share-weighted ideological distances. Third and last, we capture dispersion (or concentration) of political power with variable

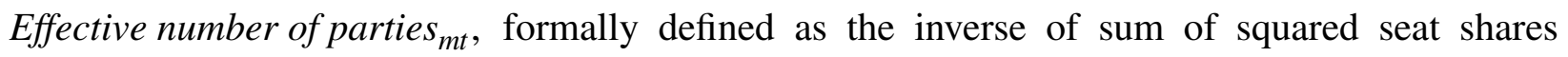
(Laakso and Taagepera 1979).

\section{Incumbency and Board Membership}

We now turn to evaluating our first prediction on the effect of incumbency on future political nominations at the individual level. A first glance at our data reveals a strong correlation between incumbency and future board nominations. Individuals who get elected at time $t$ are around 15 percentage points more likely to get selected to municipal boards than those who do not get elected in the bargaining process that follows elections at $t+1$. Incumbents are also 3 percentage points more likely to become board chairmen than non-incumbents.

\footnotetext{
${ }^{13}$ We use candidate-level survey data on policy preferences to construct a measure of party ideology. These data come from a so-called voting aid application provided by the Finnish public broadcasting company $Y L E$. The survey contains a number of questions that we compress into a single measure of party ideology using a principal component analysis. For further information, see Appendix A.
} 


\section{Regression Discontinuity Design}

A standard concern in the literature on incumbency effects is that a simple comparison of non-incumbents and incumbents would be confounded by other factors. For instance, individuals elected with large margins are potentially more capable than those individuals who were far from getting elected.

To tackle this problem, we exploit within-party close elections between candidates that stem from the Finnish open-list proportional representation system (Hyytinen et al. 2018b,a). We estimate the following regression discontinuity design (RDD) specification non-parametrically to quantify the causal effect of incumbency on future political promotion:

$$
y_{i m, t+1}=\pi+\rho \text { Elected }_{\text {imt }}+f\left({\text { Election } \left.\text { margin }_{\text {imt }}\right)}\right)+v_{\text {imt }} .
$$

Here Elected is an indicator variable for the election status of a politician $i$ running in municipality $m$ at election $t . y_{i m, t+1}$ indicates getting a board seat in bargaining process that follows after elections held at $t+1$. That is, we are interested in the incumbency effect rather than the immediate effect of getting elected. Election margin $_{\text {imt }}$ of each candidate is constructed as follows. For each party list, we define a cutoff value as the average of the within-party vote shares of the last elected and the first non-elected candidate. Each candidate's distance from election is then the difference between her within-party vote share and the cutoff value. $f\left(\right.$ Election margin $\left._{\text {imt }}\right)$ is a low-order polynomial estimated separately on each side of the cutoff, and $v_{i m t}$ is the error term.

We start with a conventional local linear approach with an MSE-optimal bandwidth (adjusted for clustering at the municipality level). This approach is MSE-optimal for point estimation but invalid for inference (Cattaneo, Idrobo, and Titiunik 2020). Following Calonico, Cattaneo, and Titiunik (2014), we thus complement the analysis with a robust bias-corrected approach which is valid for inference. This specification fits a second-order polynomial within the MSE-optimal 
bandwidth for the local linear polynomial. Robust inference is achieved by incorporating the contribution of the bias-correction step to the variability of the bias-corrected point estimator.

Three remarks regarding the sample that we use in the subsequent analyses are in order. First, our estimations are unconditional on rerunning. This is reasonable also given the institutional setting: municipal board members do not need to be elected politicians. Second, we omit politicians from parties that had all their candidates elected or non-elected, because it is not possible to define the running variable for such party lists. Third, we leave out candidates who were involved in ties for the last seat. For all such candidates, the running variable takes the value zero, resulting in a large mass point at the cutoff. Moreover, they are randomly assigned in the treatment and control groups which violates the sharp RDD assumption.

\section{Effect of Incumbency on Board Membership}

We illustrate the regression results graphically in Figure 2. Panel A first shows that there is an upward jump at the threshold for getting elected: incumbency almost doubles a politician's chances of getting selected to the board. There is no visible jump in Panel B where we look at the propensity of becoming a board chair. More detailed estimation results can be found in Panel C of Figure 2. The conventional RDD estimate suggests an increase of 2.9 percentage points in the probability of getting selected to the municipal board ( $p<0.01$ ), and the robust RDD estimate implies a 2.4 percentage point increase $(p<0.10)$. We estimate a precise zero effect on the probability of getting promoted to the board chairmanship.

The individual-level findings are in line with several possible mechanisms that we discuss in the theory section. Based on earlier research on incumbency advantage in Finnish local elections (Hyytinen et al. 2018b), we can rule out the possibility that parties would be rewarding incumbents with political promotions for to their improved electoral performance. The lack of incumbency advantage in election outcomes combined with incumbency advantage for executive seats is in line with recent arguments that the principal demand for high-quality politicians comes from parties for governing purpose rather than from voters (Cox et al. 2021; Buisseret et al. 2019). 
We assess the robustness and validity of the RDD results in Appendix B. ${ }^{14}$ As we show in Appendix Figure B1, the effect magnitude is very robust to alternative bandwidths. Appendix Figure B2 shows that the covariate smoothness assumption is satisfied. We also document that the empirical design passes a placebo threshold test (Appendix Figure B3). Lastly, McCrary (2008) test shown in Appendix Figure B4 suggests that there is no precise manipulation of the running variable at the cutoff.

\section{Value of Re-Elected Politicians in Coalitional Bargaining}

What are the implications of incumbent representation at the party level? We next test our second prediction that parties get a bargaining premium from having more incumbent politicians.

\section{Baseline Specification}

Assume that we are interested in the relationship between the share of board seats that a party $p$ in a municipality $m$ at time $t$ gets, $y_{p m t}$, and the respective seat share of incumbent politicians, Incumbent $\%_{\text {pmt }}$. We start by estimating the following specification using OLS:

$$
y_{p m t}=\alpha+\beta \text { Political power }_{p m t}+\gamma \text { Incumbent }_{\text {pomt }_{p m}}+\mu_{\text {pmt }} .
$$

We want to quantify the possible bargaining premium of having more incumbent politicians while holding the relative strength of the party fixed. The empirical literature assessing Gamson's law typically employs party seat share as a measure of its strength. Moreover, the Finnish practice of assigning board seats roughly proportionally to council seats makes this a relevant measure. However, Ansolabehere et al. (2005), among others, argue that voting weight is the most appealing

\footnotetext{
${ }^{14}$ Generally speaking, close elections have been shown provide a credible source of causal identification both in our context and many others (Hyytinen et al. 2018b; De Magalhães et al. 2020).
} 

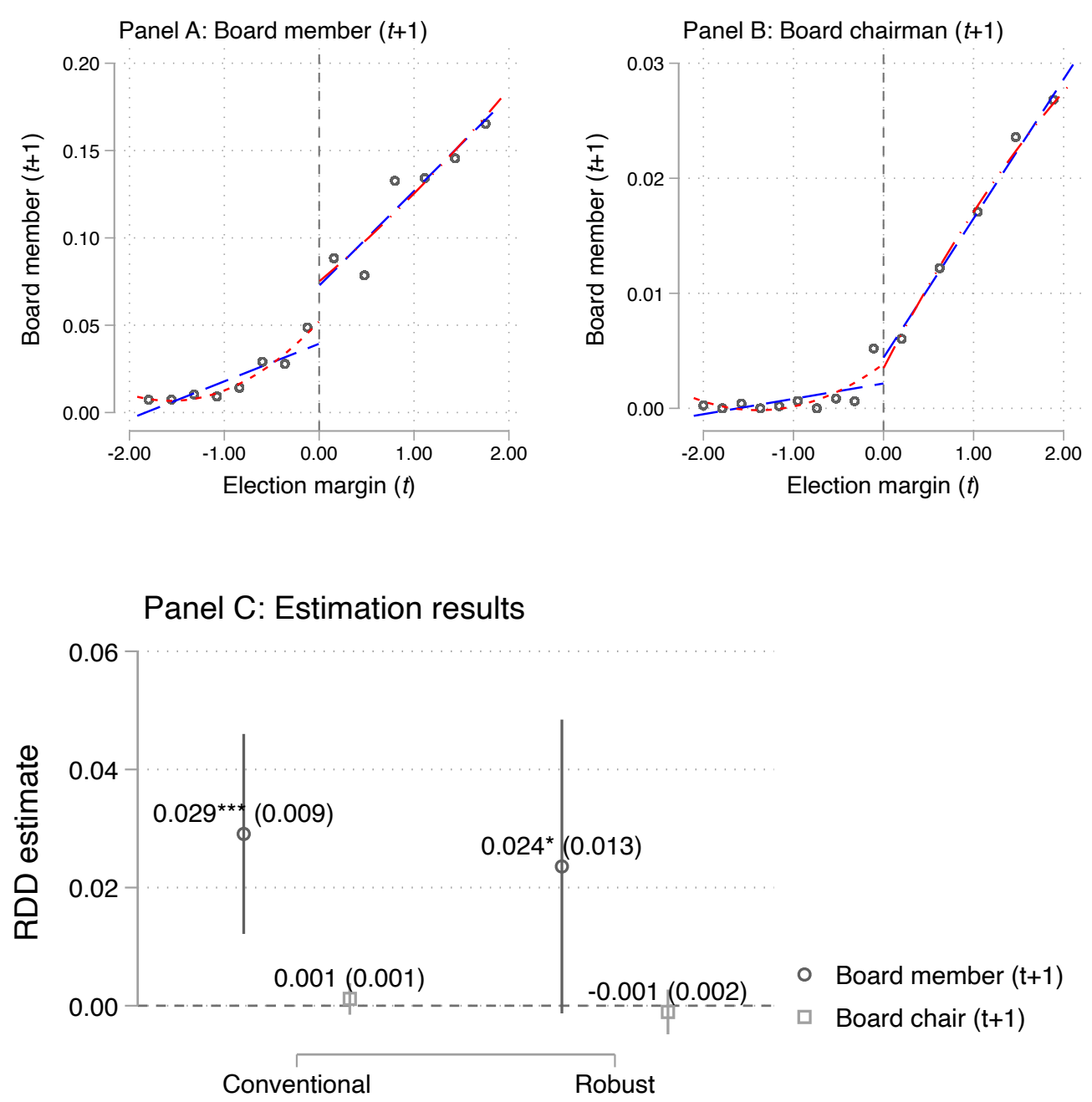

Figure 2. Incumbency and future board membership.

Notes: Panels A and B of the figure show RDD plots with local linear and quadratic polynomials and averages calculated within bins that have an equal number of observations following Calonico, Cattaneo, and Titiunik (2015). We restrict the data within the MSE-optimal bandwidth for the local linear specification. Panel C reports conventional and robust RDD estimates obtained using a local linear specification within the MSE-optimal bandwidth. We use a triangular kernel and account for clustering at the municipality level when computing the optimal bandwidths. Standard errors clustered at the municipality level are reported in parentheses. We also show $95 \%$ confidence intervals. $*, * *$ and $* * *$ denote statistical significance at $10 \%, 5 \%$ and $1 \%$ levels, respectively.

measure of a party's bargaining potential from a theoretical point of view. Given these arguments, 
we use both the party seat share and the Shapley-Shubik index to gauge political power-but not simultaneously, as they are very highly correlated. ${ }^{15}$

\section{Preliminary Analysis}

We start by illustrating graphically the correlation between incumbent representation and parties' seat shares in the executive board in Figure 3. We plot binned averages (computed within twenty bins that have an equal number of observations) and a linear fit after controlling for parties' voting power or council seat share.

Panel A of the figure first shows a strong positive correlation between incumbent seat share and share of board seats that a party obtains. Increasing incumbent seat share by one percentage point is roughly associated with a one percentage point increase in the board seat share, when we control for voting power (left-hand side graph). To better understand the magnitude of this point estimate, consider a median-sized local council with 27 councilors and a median-sized municipal board with 9 members. Then, having one more incumbent representative (instead of a non-incumbent) is roughly associated with getting $1 / 4$ of a board seat. When we control for council seat share (righthand side graph), the positive relationship remains, but it is more moderate: a one percentage point increase increase in incumbent seat share is associated with a 0.11 percentage point increase in board seat share. The slope coefficients are statistically significant with $p<0.01$.

Similarly, Panel B suggests a positive correlation between incumbents' representation and the probability of a party acquiring the board chairmanship-essentially, becoming the coalition

\footnotetext{
${ }^{15}$ Note that we may similarly encounter problems with multicollinearity because we include both party incumbent seat share and party seat share, both scaled with council size, in our regressions. This can result in inflated standard errors (Wooldridge 2001). We do not scale the number of incumbents by party size in order to avoid outliers that could arise from small parties. For example, a party that gains two seats has either $0 \%, 50 \%, 100 \%$ incumbent share. This high variance would be particularly problematic for our instrumental variable strategy.
} 
formateur. The left-hand side graph suggests that a one percentage point higher incumbent seat share is associated with a 0.7 percentage point, increase in the probability of getting to nominate the board chairperson. The regression coefficient is considerably smaller and statistically insignificant in the right-hand side graph where we net out party seat share.

Panel A: Share of board seats
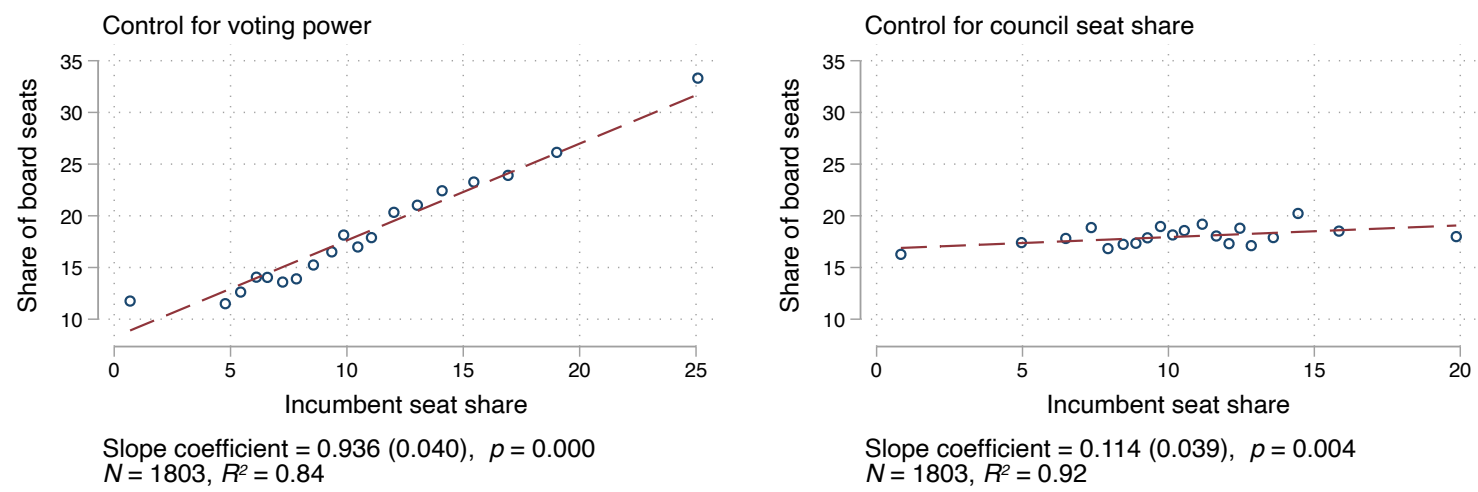

Panel B: Board chair
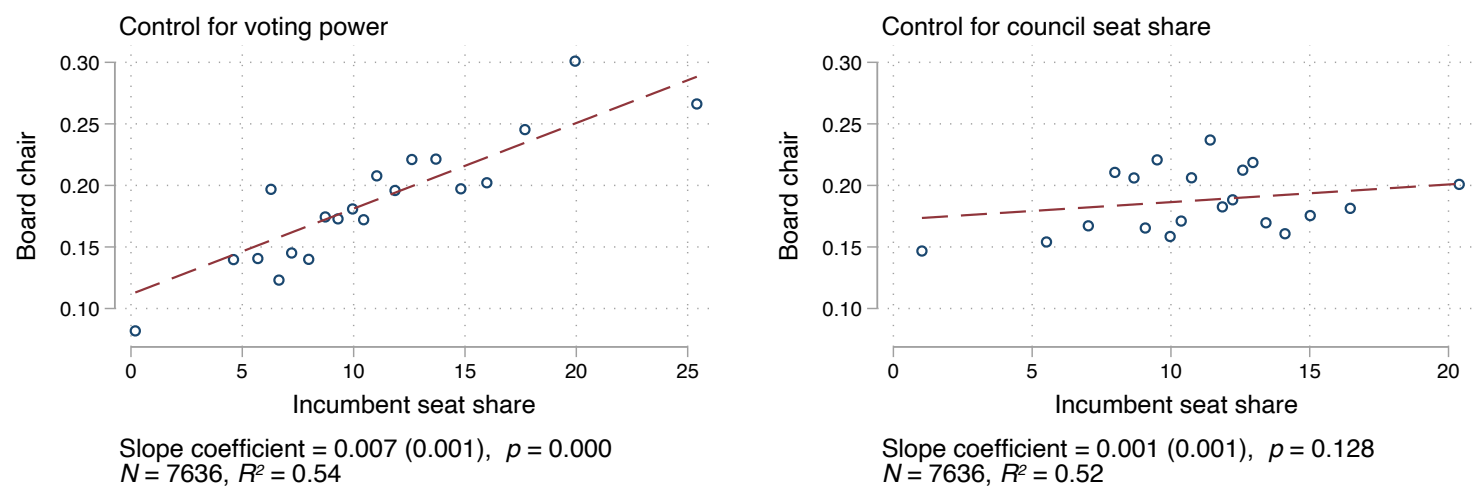

Figure 3. Re-elected incumbents' seat share and coalitional bargaining outcomes.

Notes: The figure shows binned averages within twenty bins with an equal number of observations and a linear fit after controlling for voting power or council seat share. Standard errors clustered at the municipality level are reported in parentheses.

\section{Instrumental Variables Approach}

We want to identify the effect of incumbents on board seat shares while holding parties' political power and all other factors fixed. However, the simple OLS estimation exercise might yield a 
biased estimate of the effect of incumbents on coalitional bargaining outcomes, for instance, due to potentially unobservable party characteristics that are correlated with both the dependent variable and incumbent seat share. Moreover, incumbents may be systematically different from non-incumbents in some other traits.

To tackle these concerns, we exploit within-party close elections that involve two types of politicians to construct an instrumental variable for seat shares. These close elections stem from the open-list system used in Finland. ${ }^{16}$ Our instrumental variable captures the extent to which incumbents' realized seat share exceeds or falls short of their expected seat share in close elections-but while the seat share (or voting power) of the party does not change in any direction. The instrument is constructed in two steps.

Step 1. The first step is to define candidates who are involved in close elections where the electoral outcomes can be seen as good as random. We classify candidates whose election margin lies within bandwidth $\varepsilon$ are involved in the close races, election margin being constructed as in our earlier regression-discontinuity analyses. Note that closeness can be defined only for party lists that elect at least one candidate and have at least one non-elected candidate.

We use bandwidth $\varepsilon=0.2$ for most of the results presented in the main text, but we will explore robustness to using alternative definitions of closeness. While the choice of bandwidth is somewhat ad hoc, there are some practical reasons behind it. Using too wide a bandwidth would cause covariate imbalances, but there must also be enough variation to ensure that the IV approach has statistical power. In practice, the elections within the bandwidth $\varepsilon=0.2$ are very close. Given that $\varepsilon$ is expressed in percentages, $\varepsilon=0.2$ means 2 votes out of 1,000 . The elections within this

\footnotetext{
${ }^{16}$ This approach has a flavor of a regression discontinuity design. However, as we are aggregating up from the individual candidate level races to party level, we no longer have a welldefined forcing variable. Instead of focusing on close races between the first non-elected and the last elected candidate only, we exploit information on a broader set of candidates who are involved in a close election within party.
} 
bandwidth cover about $5 \%$ of all candidates running for election. Roughly half of them are either ties resolved by a lottery or cases where the vote difference between the last elected and the first non-elected candidate is merely one vote.

Step 2. In the second step, we calculate the difference between the realized and the expected outcome of the close races within each party list $p$. This yields a number for how many more incumbent politicians are elected, by chance, from the close races than we would expect. These close races can involve more than two candidates, of which any number can be incumbents. Candidates from a group with two types of politicians (incumbents and non-incumbents) are (quasi-)randomly designated election status. As the election status of any candidate can be determined only once, the expectation comes from a hyper-geometric distribution.

Formally, the instrumental variable is then defined by equation

$$
T_{m t}=\frac{100}{S_{m t}}\left(\sum_{N_{p m t}} C_{i p m t} E_{i p m t} D_{i p m}-\frac{\sum_{N_{p m t}} C_{i p m t} D_{i p m}}{\sum_{N_{p m t}} C_{i p m t}} \sum_{N_{p m t}} C_{i p m t} E_{i p m t}\right),
$$

where $C_{i p m t}, E_{i p m t}$ and $D_{i p m}$ are dummies for a politician $i$ (from party $p$ in municipality $m$ at time $t$ ) being close, getting elected, and being incumbent, respectively. $N_{p m t}$ is the set of candidates. The first term within the parentheses is the number of incumbent candidates elected in close elections, while the second term is the expected number of such candidates. Finally, we re-scale the expression by council size $S_{m t}$ and multiply it by 100 in order to express the instrument in terms of seat share. We demonstrate the construction of the instrumental variable with a hypothetical example in Appendix C.

First Stage and Identifying Variation. Figure 4 shows the first stage of our IV analyses and also demonstrates the identifying variation. The graph shows scatter plots of incumbent seat share and the instrumental variable for it as well as linear fits using two samples: the limited sample for which we observe the board seat shares, and the full sample for which we observe the board chairmanship. There is a strong connection between the instrument and incumbent seat share. In 
the limited sample, incumbent seat share increases by 1.82 percentage points $(p<0.001)$. In the full sample, the first-stage coefficient is around $1.89(p<0.001)$. The scatter plots suggest that the actual seats typically deviate from the expected seats by one or less in those parties that have close elections, although there are some parties that have more extreme deviations. ${ }^{17}$

While incumbents may be different from non-incumbents also in other characteristics than just their past political experience, the variation that our instrument captures is plausibly random. We demonstrate this in Appendix Tables C2 and C3, where we show that parties with a positive and a negative instrument value are similar to each other not only in size but also in composition. We conjecture that close elections will credibly allow us to identify the causal effect of incumbent representation on parties' bargaining outcomes. ${ }^{18}$

In sum, our method produces an instrumental variable that is ideal in many ways. It is asgood-as random; the exclusion restriction holds; it is monotonic in the sense that an increase in the instrument deterministically increases the value of the endogenous variable (i.e., incumbent seat share); it has a strong first stage; and all units are compliers, since getting elected in a close election also simply means getting elected.

\section{Regression Results}

We then run our analyses using the instrumental variable discussed above. We do not control for voting power or party seat share in the main analysis, as it is not necessary for identification. These measures balance by construct due to the within-party, as-good-as-random research design. Figure

${ }^{17}$ Close elections happen within all parties, but they are more common in large parties; the Social Democratic Party, the Center Party, and the National Coalition Party. Appendix Figures C1 and C2 graphically illustrate the identifying variation by political party.

${ }^{18}$ To provide further evidence supporting the validity of our IV approach, we also conduct a placebo threshold analysis in Appendix Figure C3. 

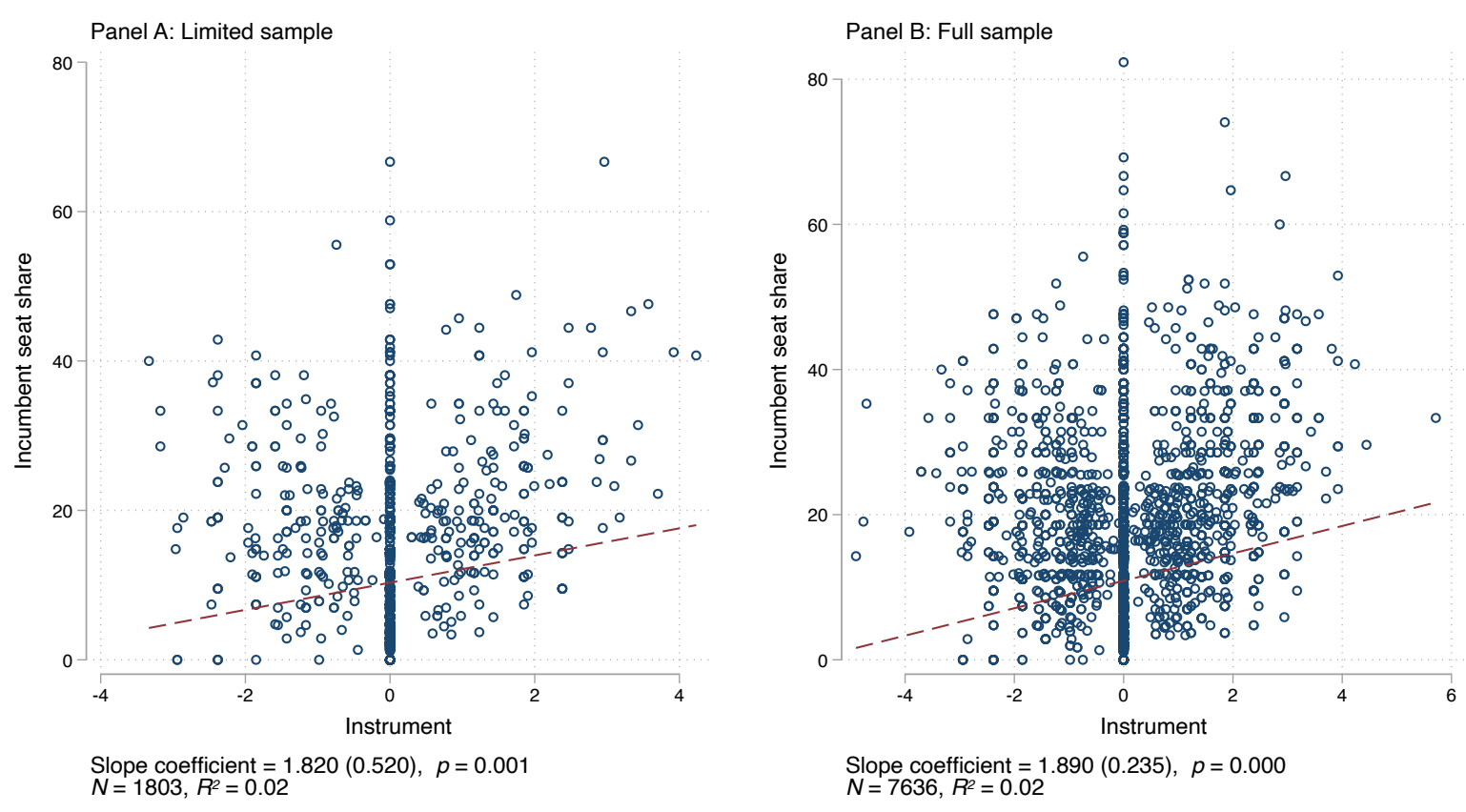

Figure 4. A graphical illustration of the first stage.

Notes: Figure shows a scatter plot of incumbent seat share and the instrumental variable, and a linear fit in the limited sample (Panel A) and the full sample (Panel B). Standard errors clustered at the municipality level are reported in parentheses.

5 presents estimation results from a 2SLS IV specification and the reduced form of IV. To ease the comparison with our preliminary analyses, we also reproduce the OLS estimates.

Let us first consider the results in Panel A of the figure. The 2SLS IV estimate is 0.72 ( $p<$ $0.05)$. The reduced form of IV estimate is around is 1.31 but not statistically significant at any conventional level. To put these effects on the scale, consider again a median-sized local council with 27 seats where one politician has a seat share of around 3.7\%. Electing one more incumbent instead of a non-incumbent thus gives a party 2.7 percentage points larger board seat share. A one standard deviation shift in the incumbent seat share $(\sigma=10.20)$ is associated with a 7.3 percentage point increase in board seat share. Given that the median board has nine seats, the effect magnitude 
is meaningful. ${ }^{19}$ Furthermore, the effect is almost as large as what we would expect parties to gain from having a one percentage point larger council seat share (also recall Figure 1).

Panel B examines the role of re-elected incumbents in becoming the formateur (and succeeding in the job). The 2SLS IV and the reduced form of IV estimates are larger than the OLS estimates. They suggest that increasing incumbents' seat share by one percentage points leads to a $1.4-2.6$ percentage points higher probability of getting to nominate the board chairperson.

Robustness checks are available in Appendix D. The results we have presented thus far are robust to controlling different measures of voting power (Appendix Tables D1 and D3). However, we do not find a statistically significant impact of incumbent representation if we augment our regression with seat share control (Appendix Table D2), which naturally stems from the fact that netting out party seat shares leaves us with considerably less variation. We further document that our conclusions remain unchanged after controlling for municipality and year fixed effects (Appendix Table D4), using alternative definitions of electoral closeness (Appendix Figure D1), or leaving out parties that do not have any close elections (Appendix Table D5).

\section{When Do Incumbents Matter the Most?}

Last, we assess the empirical support for our auxiliary predictions on how incumbent representation may interact with other party characteristics and relevant institutional factors. Robustness checks on the results presented here can be found in Appendix D.

\footnotetext{
${ }^{19}$ In Appendix E, we estimate the same models as before but decompose the dependent variable in two parts: incumbents' and non-incumbents' share of board seats. We show that incumbent representation in the local council only affects incumbents' board seat shares.
} 

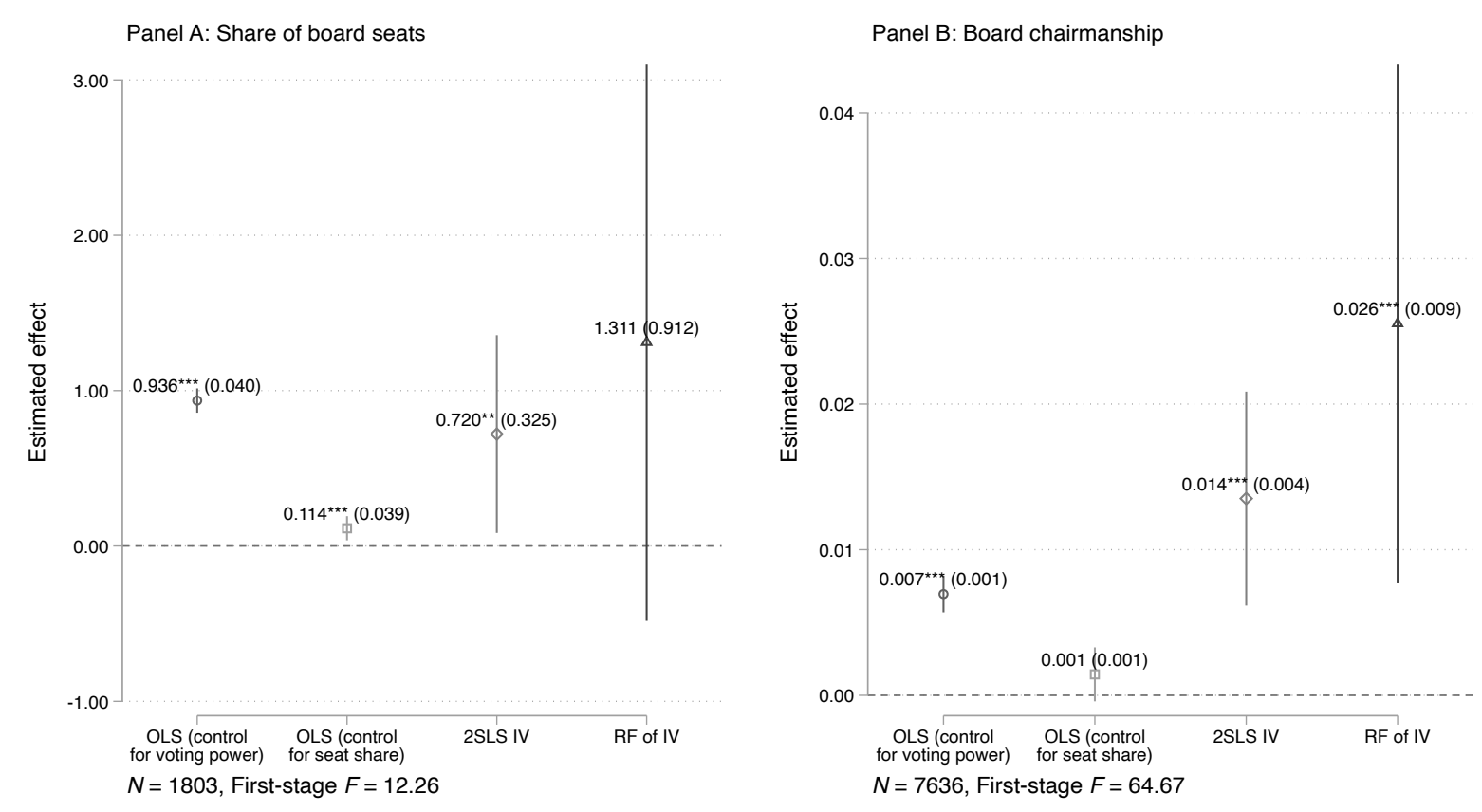

Figure 5. Effect of incumbent representation on coalitional bargaining outcomes.

Notes: The figure shows point estimates and their 95\% confidence intervals constructed using standard errors clustered at the municipality level. *** and *** denote statistical significance at $10 \%, 5 \%$ and $1 \%$ levels, respectively.

\section{Incumbent Representation and Party-Level Characteristics}

We begin by studying the interaction between incumbent seat share and party characteristics. Our focus is on descriptive analysis, as we do not have enough statistical power to estimate the interaction effects causally using our IV approach.

In columns (1)-(4) of Table 1, the dependent variable is the share of board seats, and column (5) focuses on board chairmanship. We present results from four different models. Columns (1) and (2) focus on party size and columns (3) and (5) on party ideology. Column (4) presents regression results from a full model that controls for variables related to both size and ideology.

We first see a positive correlation between a party's voting power and the share of board seats. Similarly, there is a positive relationship between incumbent seat share and the share of board 
seats or acquiring the board chairmanship. ${ }^{20}$ Furthermore, the formateur appears to enjoy a substantial advantage. ${ }^{21}$ To avoid potential post-treatment bias, we proxy coalition formateurship by an indicator for being the largest party instead of using board chairmanship. ${ }^{22}$ Namely, getting to nominate the board chairman can in addition be influenced by the voting power and the amount of incumbent representatives that a party has.

Importantly, we find that the formateur benefits from re-elected incumbents less than other parties. The interaction term Incumbent seat share $\times$ Largest party comes with a negative and statistically significant regression coefficient in all specifications. This result provides empirical support for our third prediction.

A simple legislative bargaining model with office-seeking parties would also suggest that if a party is not the coalition formateur, then having too many incumbents or too much voting power is hurtful. We thus complement our regression with quadratic polynomials of voting power and incumbent seat share as well as their interactions with an indicator for being the formateur (again proxied with a dummy for being the largest party). There is no strong evidence of convexities. Thus, it appears that parties always benefit from having more incumbent politicians, on average, providing evidence against our fourth prediction.

Our findings regarding the role of ideology, on which we did not postulate any explicit hypotheses, do not warrant any strong conclusions. There is weak evidence that a larger ideological distance from other parties could be harmful for parties' coalitional bargaining

${ }^{20}$ The marginal effect of incumbent seat share (evaluated at means) is close to one $(p<0.01)$ in column (3) and $0.01(p<0.01)$ in column $(5)$.

${ }^{21}$ The finding that the formateur party obtains a larger share of the executive seats corroborates the findings of Ansolabehere et al. (2005), even if many earlier studies have found no support for the idea. In fact, this lack of systematic evidence led Laver, de Marchi, and Mutlu (2011) to label the idea of a formateur advantage in coalition formation as a "theoretical and empirical impasse".

${ }^{22}$ This is a reasonable assumption in light of our data. Almost in $80 \%$ of the cases, the party holding the board chair position is the largest party represented in the local council. 
outcomes. However, the sign of the regression coefficient for the interaction term Ideological distance $\times$ Incumbent seat share varies depending on the specification (see also the robustness checks in Online Appendix D).

\section{Complexity of the Bargaining Environment}

We conclude the empirical analysis by exploring how the role of incumbent representation may depend on the complexity of the bargaining environment. Table 2 presents regression results from an OLS regression in which we interact incumbent seat share with each of these factors in turn. We also report results from a full specification that includes all variables.

The first two columns of the table study the relationship with the share of board seats. Column (1) suggests that the benefits of having more re-elected incumbents representing a party diminish as political power becomes more concentrated (that is to say, the effective number of parties decreases) and bargaining for the board seats ought to be more simple. The interaction effect is also statistically significant with $p<0.01$. At the same time, parties tend to get a larger share of board seats, on average. However, polarization in the local government and its interaction with incumbent seat share does not seem to matter in any meaningful way (column 2). The third column presents results from a specification that includes all variables in one regression. These results are in line with those that we report in columns (1) and (2). The next three columns focus on board chairmanship as the dependent variable, revealing a very similar pattern. ${ }^{23}$

\footnotetext{
${ }^{23}$ The marginal effect of incumbent seat share evaluated at the means is around $0.94(p<0.01)$ in columns (1)-(3) and $0.01(p<0.01)$ in columns (4)-(6).
} 
Table 1. Incumbent representation and party-level characteristics.

\begin{tabular}{|c|c|c|c|c|c|}
\hline & \multicolumn{4}{|c|}{ Share of board seats } & \multirow{2}{*}{$\frac{\text { Board chair }}{(5)}$} \\
\hline & (1) & (2) & (3) & (4) & \\
\hline Voting power & $\begin{array}{l}0.289 * * * \\
(0.017)\end{array}$ & $\begin{array}{c}0.195 * * * \\
(0.053)\end{array}$ & $\begin{array}{l}0.299 * * * \\
(0.018)\end{array}$ & $\begin{array}{c}0.184 * * * \\
(0.053)\end{array}$ & $\begin{array}{c}0.008 * * * \\
(0.000)\end{array}$ \\
\hline Incumbent seat share & $\begin{array}{l}1.110^{* * *} \\
(0.036)\end{array}$ & $\begin{array}{l}1.230 * * * \\
(0.095)\end{array}$ & $\begin{array}{l}0.796 * * * \\
(0.057)\end{array}$ & $\begin{array}{l}1.421^{* * *} \\
(0.105)\end{array}$ & $\begin{array}{c}0.004 * * * \\
(0.001)\end{array}$ \\
\hline Largest party & $\begin{array}{c}17.445^{* * *} \\
(1.176)\end{array}$ & $\begin{array}{c}18.846 * * * \\
(3.305)\end{array}$ & & $\begin{array}{l}20.095^{* * *} \\
(3.447)\end{array}$ & \\
\hline Incumbent seat share $\times$ Largest party & $\begin{array}{l}-0.744 * * * \\
(0.055)\end{array}$ & $\begin{array}{l}-1.175^{* * *} \\
(0.182)\end{array}$ & & $\begin{array}{l}-1.265^{* * *} \\
(0.186)\end{array}$ & \\
\hline Voting power ${ }^{2}$ & & $\begin{array}{c}0.002 \\
(0.002)\end{array}$ & & $\begin{array}{c}0.002 \\
(0.002)\end{array}$ & \\
\hline Incumbent seat share ${ }^{2}$ & & $\begin{array}{l}-0.005 \\
(0.005)\end{array}$ & & $\begin{array}{l}-0.008 \\
(0.005)\end{array}$ & \\
\hline Voting power $\times$ Largest party & & $\begin{array}{c}0.185 \\
(0.146)\end{array}$ & & $\begin{array}{c}0.167 \\
(0.147)\end{array}$ & \\
\hline Voting power $^{2} \times$ Largest party & & $\begin{array}{l}-0.003 \\
(0.002)\end{array}$ & & $\begin{array}{l}-0.003 \\
(0.002)\end{array}$ & \\
\hline Incumbent seat share ${ }^{2} \times$ Largest party & & $\begin{array}{c}0.009 \\
(0.006)\end{array}$ & & $\begin{array}{l}0.011^{*} \\
(0.006)\end{array}$ & \\
\hline Ideological distance & & & $\begin{array}{c}-2.537 * * * \\
(0.477)\end{array}$ & $\begin{array}{l}-0.189 \\
(0.431)\end{array}$ & $\begin{array}{c}-0.057 * * * \\
(0.006)\end{array}$ \\
\hline Incumbent seat share $\times$ Ideological distance & & & $\begin{array}{c}0.288 * * * \\
(0.063)\end{array}$ & $\begin{array}{l}-0.190 * * * \\
(0.058)\end{array}$ & $\begin{array}{c}0.006 * * * \\
(0.001)\end{array}$ \\
\hline Constant & $\begin{array}{l}1.536 * * * \\
(0.225)\end{array}$ & $\begin{array}{l}1.564 * * * \\
(0.283)\end{array}$ & $\begin{array}{c}4.223 * * * \\
(0.365)\end{array}$ & $\begin{array}{c}1.640 * * * \\
(0.361)\end{array}$ & $\begin{array}{c}-0.018^{* * *} \\
(0.005)\end{array}$ \\
\hline$N$ & 1803 & 1803 & 1799 & 1799 & 7423 \\
\hline$R^{2}$ & 0.87 & 0.87 & 0.85 & 0.87 & 0.54 \\
\hline
\end{tabular}

Notes: Standard errors clustered at the municipality level are reported in parentheses. *, ** and *** denote statistical significance at $10 \%, 5 \%$ and $1 \%$ levels, respectively. 


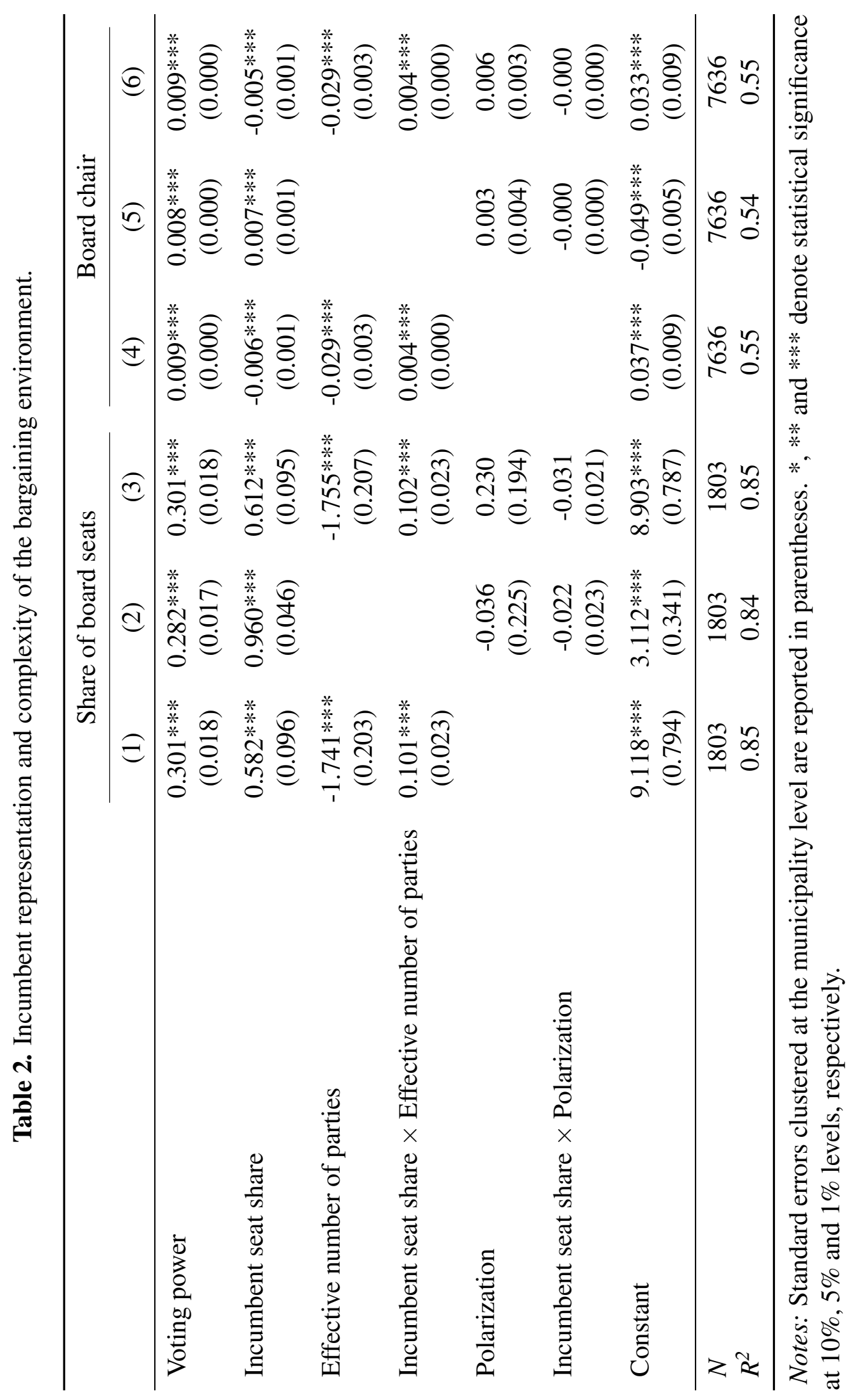




\section{Concluding Remarks}

We propose a novel argument and present evidence from Finnish municipalities that there is an incumbency advantage in government formation. We first document that incumbent politicians are more likely to get promoted to the local executive. This finding carries on to the party level: parties that have more incumbent representatives gain more seats in the executive municipal board than otherwise similar parties. Descriptive analyses suggest that having more re-elected incumbents could be particularly useful for disadvantaged parties and in complex bargaining environments. Thus, incumbents appear to make the bargaining process less costly, for example, due to networks and trust gained while in office. Our results provide one rationale for why parties have reason to demand politically experienced candidates.

The lessons from our study may be applicable elsewhere. For instance, local governments are key players in political systems across Europe (Stoker 1991), and in many countries, they have institutional arrangements similar to those in Finland. In fact, inspired by our analysis, Fiva, Izzo, and Tukiainen (2020) document a similar incumbency advantage in coalitional bargaining in Norway. Furthermore, our empirical case shares similarities with the selection of parliamentary committees that have an important role in legislatures around the world (Strøm 1998). Whether an incumbency advantage arises in such cases would be an interesting avenue for subsequent work.

An important feature of our setting is that all parties that are represented in the local council typically obtain representation in the executive board. Whether our findings generalize to the formation of governing coalitions in national politics, where coalition formation is a more complex process among many other institutional differences, thus calls for more theoretical and empirical research. As a first step, we have collected information on parties and the allocation of cabinet positions in Finland, Norway (from Fiva and Smith 2017 and Cox et al. 2021), and Ireland (from Smith and Martin 2017). Findings from these data-that we present in Appendix Figure F1 - are encouraging and in line with our main hypothesis and result, but they also leave room for future comparative research. In particular, we abstract from a fundamental aspect of coalition 
formation in typical settings, namely which parties get to be part of the governing coalition. Whether incumbency plays a role at this margin and in different institutional settings more broadly ought to be studied further.

Lastly, our study bears methodological implications. Formal models of bargaining applied in the political arena typically attribute the final result of bargaining to parties' seat shares or their voting power, although some models investigate the role of party ideology. We show that parties' bargaining power and bargaining outcomes do not only depend on such attributes but also on the characteristics of their representatives. Moreover, our example shows that representation may interact with other party characteristics. In our view, it would be important to reconcile these phenomena with a comprehensive, micro-founded model.

\section{References}

Ansolabehere, Stephen, James M. Snyder, Aaron B. Strauss, and Michael M. Ting. 2005. "Voting Weights and Formateur Advantages in the Formation of Coalition Governments." American Journal of Political Science 49 (3): 550-563.

Ansolabehere, Stephen, James M. Snyder, and Charles Stewart. 2001. "Candidate Positioning in U.S. House Elections.” American Journal of Political Science 45 (1): 136-159.

Baron, David P. 1991. “A Spatial Bargaining Theory of Government Formation in Parliamentary Systems.” American Political Science Review 85 (1): 137-164.

Baron, David P. 1993. "Government Formation and Endogenous Parties.” American Political Science Review 87 (1): 34-47.

Baron, David P., and John A. Ferejohn. 1989. "Bargaining in Legislatures." American Political Science Review 83 (4): 1181-1206.

Bassi, Anna. 2013. “A Model of Endogenous Government Formation.” American Journal of Political Science 57 (4): 777-793. 
Bassi, Anna. 2017. "Policy Preferences in Coalition Formation and the Stability of Minority and Surplus Governments.” Journal of Politics 79 (1): 250-268.

Blockmans, Tom, Benny Geys, Bruno Heyndels, and Bram Mahieu. 2016. "Bargaining complexity and the duration of government formation: evidence from Flemish municipalities." Public Choice 167 (1): 131-143.

Browne, Eric C., and John P. Frendreis. 1980. "Allocating Coalition Payoffs by Conventional Norm: An Assessment of the Evidence from Cabinet Coalition Situations." American Journal of Political Science 24 (4): 753-768.

Browne, Eric C., and Mark N. Franklin. 1973. "Aspects of Coalition Payoffs in European Parliamentary Democracies.” American Political Science Review 67 (2): 453-469.

Browne, Eric C., and Peter Rice. 1979. “A Bargaining Theory of Coalition Formation.” British Journal of Political Science 9 (1): 67-87.

Buisseret, Peter E., Olle Folke, Carlo Prato, and Johanna Rickne. 2019. "Party Nomination Strategies in List Proportional Representation Systems." Working paper. Available online at https://ssrn. com/abstract=3425692.

Bäck, Hanna, Marc Debus, and Patrick Dumont. 2011. "Who gets what in coalition governments? Predictors of portfolio allocation in parliamentary democracies." European Journal of Political Research 50 (4): 441-478.

Bäck, Hanna, and Patrick Dumont. 2008. "Making the First Move: A Two-Stage Analysis of the Role of Formateurs in Parliamentary Government Formation." Public Choice 135 (3/4): 353373.

Calonico, Sebastian, Matias D. Cattaneo, and Rocio Titiunik. 2014. "Robust Nonparametric Confidence Intervals for Regression-Discontinuity Designs.” Econometrica 82 (6): 2295-2326. 
Calonico, Sebastian, Matias D. Cattaneo, and Rocío Titiunik. 2015. "Optimal Data-Driven Regression Discontinuity Plots.” Journal of the American Statistical Association 110 (512): 1753-1769.

Cattaneo, Matias, Nicolás Idrobo, and Rocío Titiunik. 2020. A Practical Introduction to Regression Discontinuity Designs: Foundations. Cambridge Elements: Quantitative and Computational Methods for Social Science. Cambridge University Press.

Cirone, Alexandra, Gary W. Cox, and Jon H. Fiva. 2020. "Seniority-based Nominations and Political Careers." Forthcoming in American Political Science Review.

Cox, Gary W., Jon H. Fiva, Daniel M. Smith, and Rune J. Sørensen. 2021. "Moral Hazard in Electoral Teams." Working paper. Available online at https://www.jon.fiva.no/docs/ CoxFivaSmithSorensen2021.pdf.

De Magalhães, Leandro, Dominik Hangartner, Salomo Hirvonen, Jaakko Meriläinen, Nelson Ruiz, and Janne Tukiainen. 2020. "How Much Should We Trust Regression Discontinuity Design Estimates? Evidence from Experimental Benchmarks of the Incumbency Advantage.” Working paper. Available online at https://preprints.apsanet.org/engage/apsa/ article-details/5f1a03d613857400119c3b13.

Diermeier, Daniel, and Antonio Merlo. 2004. "An empirical investigation of coalitional bargaining procedures." Journal of Public Economics 88 (3): 783-797.

Ecker, Alejandro. 2019. "vpowerin: Stata module to calculate various voting power indices." Available online at https://github.com/eckerale/vpowerin.

Ecker, Alejandro, Thomas M. Meyer, and Wolfgang C. Müller. 2015. "The distribution of individual cabinet positions in coalition governments: A sequential approach." European Journal of Political Research 54 (4): 802-818. 
Eguia, Jon X., and Kenneth A. Shepsle. 2015. "Legislative Bargaining with Endogenous Rules." Journal of Politics 77 (4): 1076-1088.

Epstein, David, David Brady, Sadafumi Kawato, and Sharyn O'Halloran. 1997. “A Comparative Approach to Legislative Organization: Careerism and Seniority in the United States and Japan.” American Journal of Political Science 41 (3): 965-998.

Falcó-Gimeno, Albert, and Indridi H. Indridason. 2013. “Uncertainty, Complexity, and Gamson’s Law: Comparing Coalition Formation in Western Europe.” West European Politics 36 (1): 221247.

Fiva, Jon, Federica Izzo, and Janne Tukiainen. 2020. "Endogenous Ballot Structures: Theory and Evidence.” Unpublished manuscript.

Fiva, Jon H., and Daniel M. Smith. 2017. "Norwegian parliamentary elections, 1906-2013: representation and turnout across four electoral systems." West European Politics 40 (6): 13731391.

Fouirnaies, Alexander, and Andrew B. Hall. 2014. "The Financial Incumbency Advantage: Causes and Consequences.” Journal of Politics 76 (3): 711-724.

Franklin, Mark N., and Thomas T. Mackie. 1983. "Familiarity and Inertia in the Formation of Governing Coalitions in Parliamentary Democracies.” British Journal of Political Science 13 (3): 275-298.

Freier, Ronny, and Sebastian Thomasius. 2016. "Voters prefer more qualified mayors, but does it matter for public finances? Evidence for Germany." International Tax and Public Finance 23 (5): 875-910.

Fréchette, Guillaume R., John H. Kagel, and Steven F. Lehrer. 2003. "Bargaining in Legislatures: An Experimental Investigation of Open versus Closed Amendment Rules." American Political Science Review 97 (2): 221-232. 
Fujiwara, Thomas, and Carlos Sanz. 2019. "Rank Effects in Bargaining: Evidence from Government Formation.” Review of Economic Studies 87 (3): 1261-1295.

Gamson, William A. 1961. “A Theory of Coalition Formation.” American Sociological Review 26 (3): 373-382.

Gelman, Andrew, and Gary King. 1990. "Estimating Incumbency Advantage without Bias." American Journal of Political Science 34 (4): 1142-1164.

Glasgow, Garrett, Matt Golder, and Sona N. Golder. 2011. "Who "Wins”? Determining the Party of the Prime Minister.” American Journal of Political Science 55 (4): 937-954.

Golder, Sona N. 2010. "Bargaining Delays in the Government Formation Process.” Comparative Political Studies 43 (1): 3-32.

Hyytinen, Ari, Jaakko Meriläinen, Tuukka Saarimaa, Otto Toivanen, and Janne Tukiainen. 2018a. "Public Employees as Politicians: Evidence from Close Elections.” American Political Science Review 112 (1): 68-81.

Hyytinen, Ari, Jaakko Meriläinen, Tuukka Saarimaa, Otto Toivanen, and Janne Tukiainen. $2018 \mathrm{~b}$. "When does regression discontinuity design work? Evidence from random election outcomes." Quantitative Economics 9 (2): 1019-1051.

Jacobson, Gary C. 1989. "Strategic Politicians and the Dynamics of US House Elections, 19461986." American Political Science Review 83 (3): 773-794.

Laakso, Markku, and Rein Taagepera. 1979. “"Effective” Number of Parties: A Measure with Application to West Europe.” Comparative Political Studies 12 (1): 3-27.

Laver, Michael. 1998. "Models of Government Formation.” Annual Review of Political Science $1(1): 1-25$.

Laver, Michael, Scott de Marchi, and Hande Mutlu. 2011. "Negotiation in legislatures over government formation." Public Choice 147: 285-304. 
Levitt, Steven D., and Catherine D. Wolfram. 1997. "Decomposing the Sources of Incumbency Advantage in the U. S. House.” Legislative Studies Quarterly 22 (1): 45-60.

Martin, Lanny W., and Georg Vanberg. 2003. "Wasting Time? The Impact of Ideology and Size on Delay in Coalition Formation.” British Journal of Political Science 33 (2): 323-332.

Martin, Lanny W., and Randolph T. Stevenson. 2001. "Government Formation in Parliamentary Democracies." American Journal of Political Science 45 (1): 33-50.

Martin, Lanny W., and Randolph T. Stevenson. 2010. "The Conditional Impact of Incumbency on Government Formation.” American Political Science Review 104 (3): 503-518.

Mattila, Mikko, and Tapio Raunio. 2004. "Does winning pay? Electoral success and government formation in 15 West European countries.” European Journal of Political Research 43 (2): 263285.

McCrary, Justin. 2008. "Manipulation of the running variable in the regression discontinuity design: A density test." Journal of Econometrics 142 (2): 698-714.

McKelvey, Richard D., and Raymond Riezman. 1992. "Seniority in Legislatures." American Political Science Review 86 (4): 951-965.

Meriläinen, Jaakko, and Janne Tukiainen. 2018. "Rank effects in political promotions.” Public Choice 177 (1-2): 87-109.

Meriläinen, Jaakko. 2020. "Politician Quality, Fiscal Policy and Ideology." Working paper. Available online at https://papers.ssrn.com/sol3/papers.cfm?abstract_id= 3741701.

Mershon, Carol. 2001. "Contending Models of Portfolio Allocation and Office Payoffs to Party Factions: Italy, 1963-79.” American Journal of Political Science 45 (2): 277-293.

Muthoo, Abhinay, and Kenneth A. Shepsle. 2014. "Seniority and Incumbency in Legislatures." Economics \& Politics 26 (1): 13-37. 
Shapley, Lloyd S., and Martin Shubik. 1954. "A Method for Evaluating the Distribution of Power in a Committee System.” American Political Science Review 48 (3): 787-792.

Smith, Daniel M., and Shane Martin. 2017. "Political Dynasties and the Selection of Cabinet Ministers.” Legislative Studies Quarterly 42 (1): 131-165.

Stoker, Gerry. 1991. The Politics of Local Government. Basingstoke: Palgrave Macmillan.

Strøm, Kaare. 1998. "Parliamentary committees in European democracies.” Journal of Legislative Studies 4 (1): 21-59.

Warwick, Paul V., and James N. Druckman. 2001. "Portfolio Salience and the Proportionality of Payoffs in Coalition Governments.” British Journal of Political Science 31 (4): 627-649.

Warwick, Paul V., and James N. Druckman. 2006. “The portfolio allocation paradox: An investigation into the nature of a very strong but puzzling relationship." European Journal of Political Research 45 (4): 635-665.

Wooldridge, Jeffrey M. 2001. Econometric Analysis of Cross Section and Panel Data. Cambridge, MA: MIT Press. 


\title{
The Advantage of Incumbents in Coalitional Bargaining Online Appendix
}

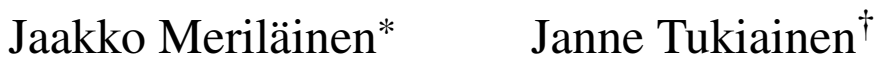

October 21, 2021

*Corresponding author. Centro de Investigación Económica and Department of Economics, ITAM, Camino Santa Teresa 930, Héroes de Padierna, Magdalena Contreras, 10700 Ciudad de México, Mexico. Email: jaakko.merilainen@itam.mx. Tel: +525582327639 .

${ }^{\dagger}$ Department of Economics, Turku School of Economics, Rehtorinpellonkatu 3, FI-20014 University of Turku; VATT Institute for Economic Research, Arkadiankatu 7, Helsinki FI-00101. Email: janne.tukiainen@utu.fi. Tel: +358295519451. 


\section{Contents}

$\begin{array}{lll}\text { A Data } & \text { OA-3 }\end{array}$

A.1 Summary Statistics and Data Sources . . . . . . . . . . . . OA-3

A.2 Measuring Ideology . . . . . . . . . . . . . . . . . OA-6

B Robustness and Validity Checks for RDD $\quad$ OA-8

$\begin{array}{lll}\text { C Instrumental Variables Approach } & \text { OA-13 }\end{array}$

C.1 Illustrative Example . . . . . . . . . . . . . . . . . OA-13

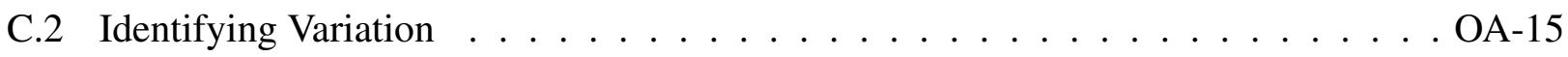

C.3 Validity Checks . . . . . . . . . . . . . . . . . OA-17

D Robustness Checks: Party-Level Results $\quad$ OA-20

D.1 Robustness of the Main Results . . . . . . . . . . . . . . . . . . OA-20

D.2 Robustness of the Heterogeneity Analyses . . . . . . . . . . . . . . . . OA-27

E Implications for Selection $\quad$ OA-34

$\begin{array}{lll}\text { F External Validity } & \text { OA-41 }\end{array}$ 


\section{A Data}

This appendix provides additional information on our data.

\section{A.1 Summary Statistics and Data Sources}

We combine information on candidates, electoral results, and post-electoral bargaining. Our election data cover four elections between the years 2000-2012, and they come from the Ministry of Justice. These data include information such as candidates' party affiliation, number of votes, previous political experience and election status. In total, the data cover 155,284 candidate-election year observations, out of which over 90,263 are unique individuals. We combine these information with data on chairmen and members of the municipal executive boards. These proprietary data come from the Finnish Association of Local Authorities (Kuntaliitto). The chairman data are available for all the above electoral terms, but the board members are observed only for the 2009-2012 electoral term. Lastly, we use candidate-level survey data on economic policy preferences of candidates running in the 2008 election to construct different metrics of party ideology. Further details on these data can be found below. Panel A of Table A1 reports descriptive statistics on the candidate-level data that are relevant for our subsequent empirical investigation.

In most of our analyses, we do not use the individual-level data but instead collapse them to the party level. Summary statistics on the party-level data can be found in Panel B of Table A1. We focus on parties that acquire at least one seat in the municipal election and thus participate in the coalitional bargaining process. Furthermore, we rule out municipalities where one party holds all seats. At most, we use 7,662 (party-electoral term) observations, although the analyses on board members only use 1,803 observations.

The average party holds almost one fifth of the local council seats and a roughly corresponding share of the board seats. We also use the Shapley-Shubik index to capture parties' voting power (Shapley and Shubik 1954). This index measures the political power of a party as the fraction of 
possible votes in which the party is decisive for the outcome of the vote. The index takes values between zero (a party cannot affect the outcome of the vote) and one (a party has an absolute majority).

Besides political power, ideology may fundamentally influence coalition formation. The survey data allow us to capture how different each party is from the other parties in the local council. Large deviations from the average policy position of the local council could be an indication of a party being in a tougher position to bargain for the board seats. For each of party $p$ in municipality $m$ at time $t$, we define ideological distance as the deviation between their policy position $\left(x_{p m t}\right)$ and the seat share weighted average policy position of the local council $\left(\hat{x}_{m t}\right)$, or more formally, $\left|x_{p m t}-\hat{x}_{m t}\right|$.

At most, we exploit data from 1,124 municipality-election pairs. In the limited sample for which we observe the municipal board composition, our data cover 332 clusters. Some of our analyses make use of municipality-level variables to capture the complexity of the bargaining environment. Panel C of Table A1 provides descriptive statistics on these as well as some other municipality-level characteristics. Importantly, we capture local council fragmentation with the effective number of parties, formally defined as the inverse of the sum of seat shares. Smaller values of this reflect more concentrated power. We also measure polarization (or ideological dispersion) at the local level based on our survey data on candidates' policy positions. We define polarization of the local council as the sum of seat share weighted deviations between each party's ideology and the seat share weighted average of policy position: $\sum_{p m t} s_{p m t}\left|x_{p m t}-\hat{x}_{m t}\right|$. 
Table A1. Summary statistics.

\begin{tabular}{lccc}
\hline & $N$ & Mean & Std. dev. \\
\hline Panel A: Individual-level variables & & & \\
Board member & 38567 & 0.08 & 0.27 \\
Board chair & 155284 & 0.01 & 0.10 \\
Elected & 155284 & 0.29 & 0.45 \\
Incumbent & 155284 & 0.21 & 0.41 \\
Election margin & 150763 & -1.51 & 6.72 \\
\hline Panel B: Party-level variables & & & \\
Board seat share & 1803 & 17.98 & 17.77 \\
Board chairmanship & 7636 & 0.19 & 0.39 \\
Voting power & 7636 & 19.29 & 27.34 \\
Council seat share & 7636 & 19.29 & 17.17 \\
Incumbent seat share & 7636 & 10.95 & 10.66 \\
Ideological distance & 7423 & 0.62 & 0.41 \\
\hline Panel C: Municipality-level variables & & & \\
Effective number of parties & 1124 & 3.19 & 0.98 \\
Polarization & 1124 & 0.86 & 0.74 \\
Council size & 1124 & 28.86 & 10.78 \\
Board size & 1124 & 7.57 & 3.61 \\
\hline
\end{tabular}




\section{A.2 Measuring Ideology}

Some of our analyses make use of party ideology that we measure using so-called voting aid application data from the Finnish public broadcasting company Yle. Voting aid applications are interactive questionnaires, the purpose of which is to assist voters in finding a candidate with similar policy preferences to theirs. Candidates fill out the survey before elections, after which voters can take the same survey to find a suitable candidate. The voting aid applications include a number of claims mostly related to the size of the public sector and redistribution, such as: "It is too easy to obtain welfare benefits nowadays" and "User fees of municipal services should be more progressive". A stronger agreement with the first claim is associated with a more right-leaning ideology, whereas the stronger agreement with the latter two claims is related to a more liberal ideology. Overall, the data contain seven claims. The candidates would give their answers on a 1-4 scale (from "completely disagree" to "completely agree").

We employ a principal component analysis to compress the survey responses into a single measure of economic policy preferences. This is a commonly used approach to extract a onedimensional measure of ideology from survey data (Heckman and Snyder 1997; Ansolabehere, Snyder, and Stewart 2001). The first principal component captures the left-right dimension of economic ideology and explains about $28 \%$ of the variation in the data. Table A2 reports results of the principal component analysis alongside with the questions included in our data. Claims where a stronger agreement implies more right-wing attitudes get larger positive values, whereas the opposite is true for claims where a stronger agreement is in line with more left-wing preferences. 
Table A2. PCA results.

\begin{tabular}{lccc}
\hline & Loading & Mean & Standard deviation \\
\hline $\begin{array}{l}\text { Q1. If necessary, it is better to increase the municipal income tax than cut } \\
\text { local public services. }\end{array}$ & -0.38 & 1.89 & 0.79 \\
Q2. It is too easy to obtain welfare benefits nowadays. & & & \\
Q3. We should compromise on environmental protection if it can improve & 0.33 & 2.92 & 0.79 \\
employment or citizens' welfare. & & & 0.81 \\
Q4. Our municipality should fire some of the employees, as there are too & 0.45 & 3.18 & 0.79 \\
many of them. & & & \\
Q5. User fees of municipal services should be more progressive. & -0.15 & 2.62 & 0.91 \\
Q6. If one of the parents is at home, the children should not be eligible & 0.41 & 2.80 & 0.91 \\
for public day care. & & & \\
Q7. If necessary, it is better to cut funding from public health care than & 0.30 & 2.71 & 0.89 \\
schools, since there is no private schooling available. & & & \\
\hline Eigenvalue & 1.96 & & \\
Proportion & 0.28 & & \\
\hline
\end{tabular}




\section{B Robustness and Validity Checks for RDD}

This appendix presents robustness and validity checks for the RDD analyses on incumbency effects. We first show in Figure B1 that our results are robust to alternative choices of bandwidth. When we make the bandwidth smaller, the confidence intervals become wider but our qualitative conclusions remain unchanged.

A number of additional analyses support the validity of our RDD results. Figure B3 plots regression discontinuity estimates and their 95\% confidence intervals that are obtained using placebo cutoffs. We see that in Panel A, where we look at the actual (marked with vertical lines) and placebo effects on board membership, we mainly detect statistically significant effects around the true cutoff. The point estimates fluctuate around zero for the artificial thresholds. Hyytinen et al. (2018) and De Magalhães et al. (2020) argue that this is a good indication of the suitability of the specification that we use.

We also do not find any evidence of sorting at the threshold. Figure B2 examines covariate smoothness. We focus on incumbency at time $t$ and show regression results from the conventional and robust RDD specifications. We report results using the (full) 2000-2012 sample. The covariate smoothness test raises no concerns. Last, the McCrary (2008) density discontinuity test in Figure B4 suggests that there is no precise manipulation of the running variable at the cutoff. 


\section{Panel A: Board member}
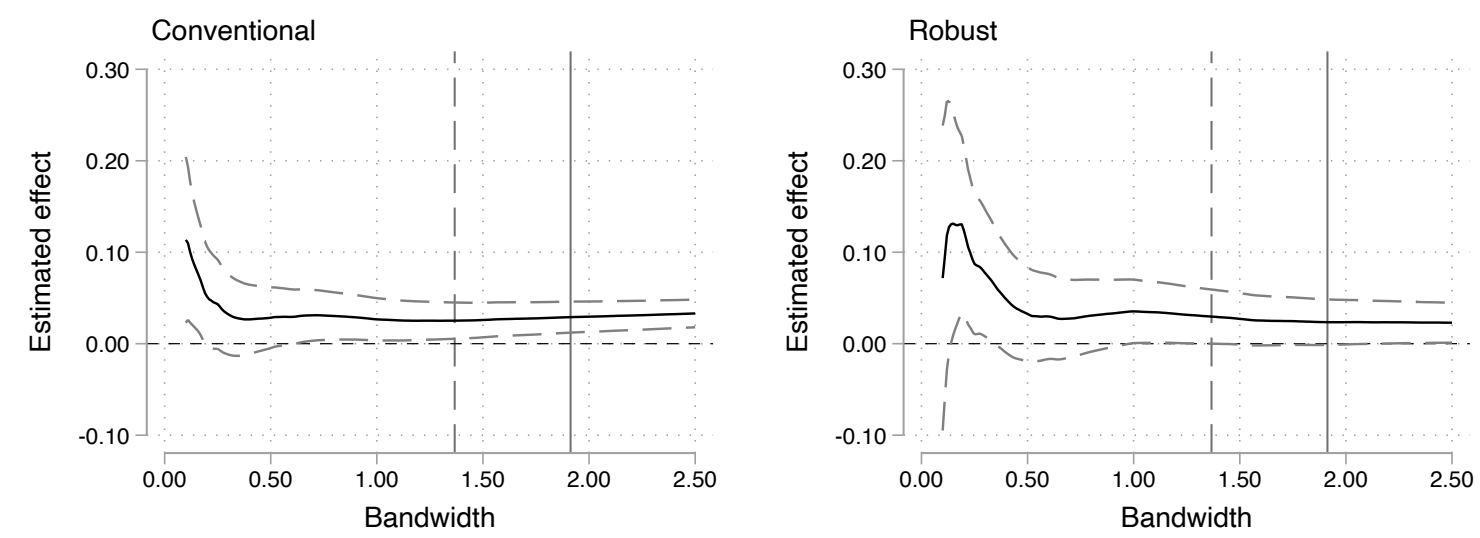

Panel B: Board chair
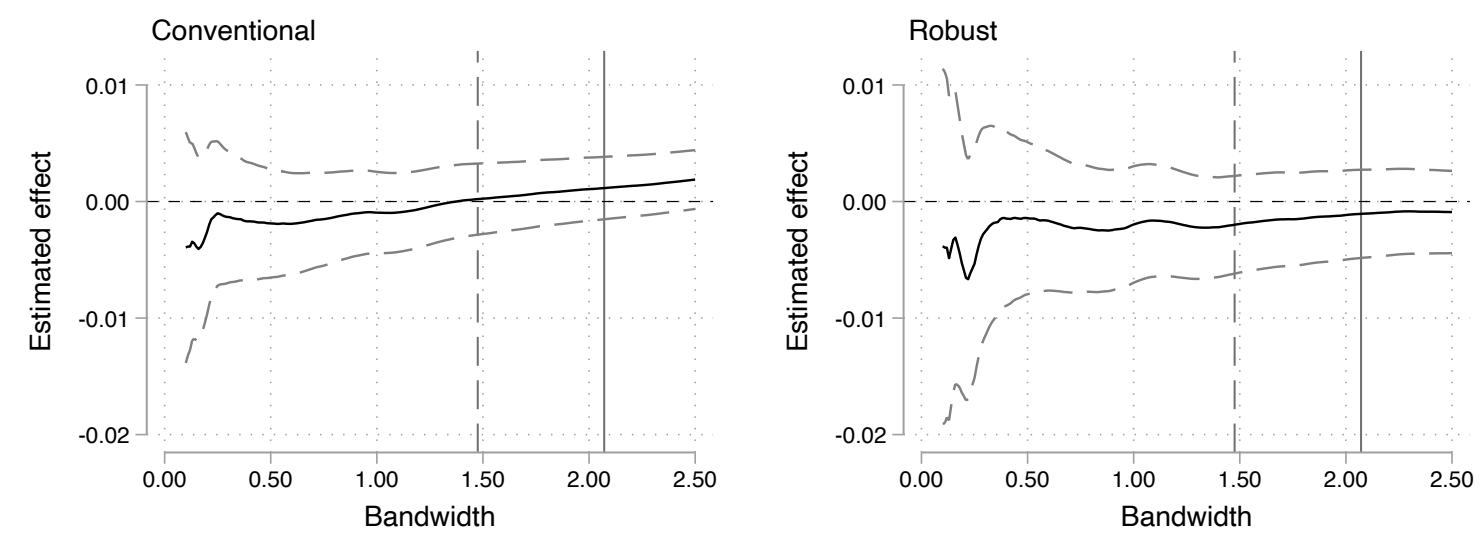

Figure B1. Robustness to alternative bandwidths.

Notes: The figure shows point estimates and their 95\% confidence intervals (constructed based on standard errors that are clustered at the municipality level) that are obtained using alternative bandwidths. The solid vertical line marks the MSE-optimal bandwidth, and the dashed vertical line is the CER-optimal bandwidth (see Calonico, Cattaneo, and Farrell 2020). All estimations use a triangular kernel, and the robust estimation fixes the main and bias bandwidths to be the same. The confidence intervals are constructed using standard errors clustered at the municipality level. 


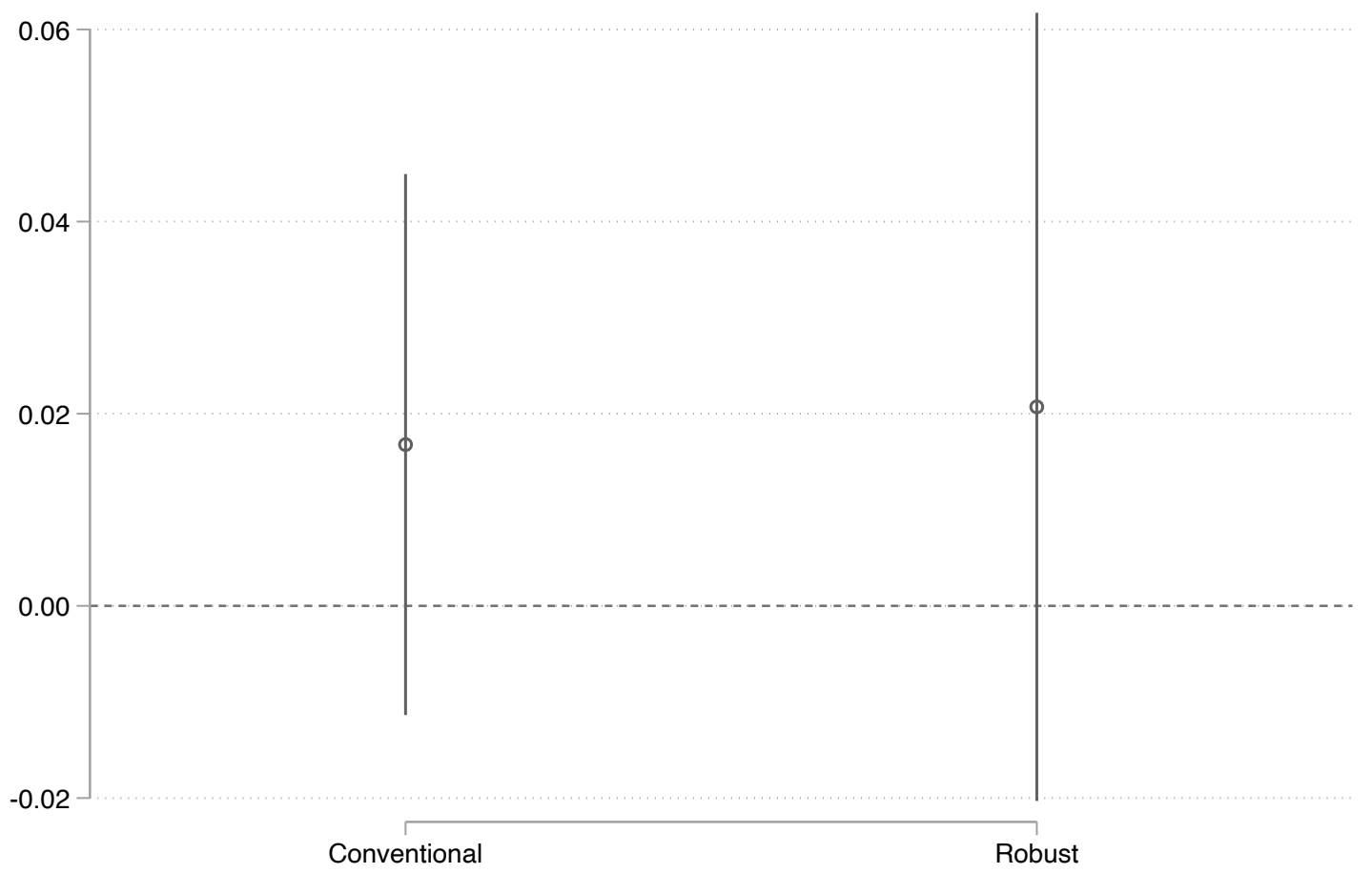

Figure B2. Covariate smoothness test.

Notes: The dependent variable is incumbency after election $t-1$. The figure shows regression discontinuity estimates and their 95\% confidence intervals constructed using standard errors clustered at the municipality level. Both estimations use a triangular kernel and MSE-optimal bandwidths. 

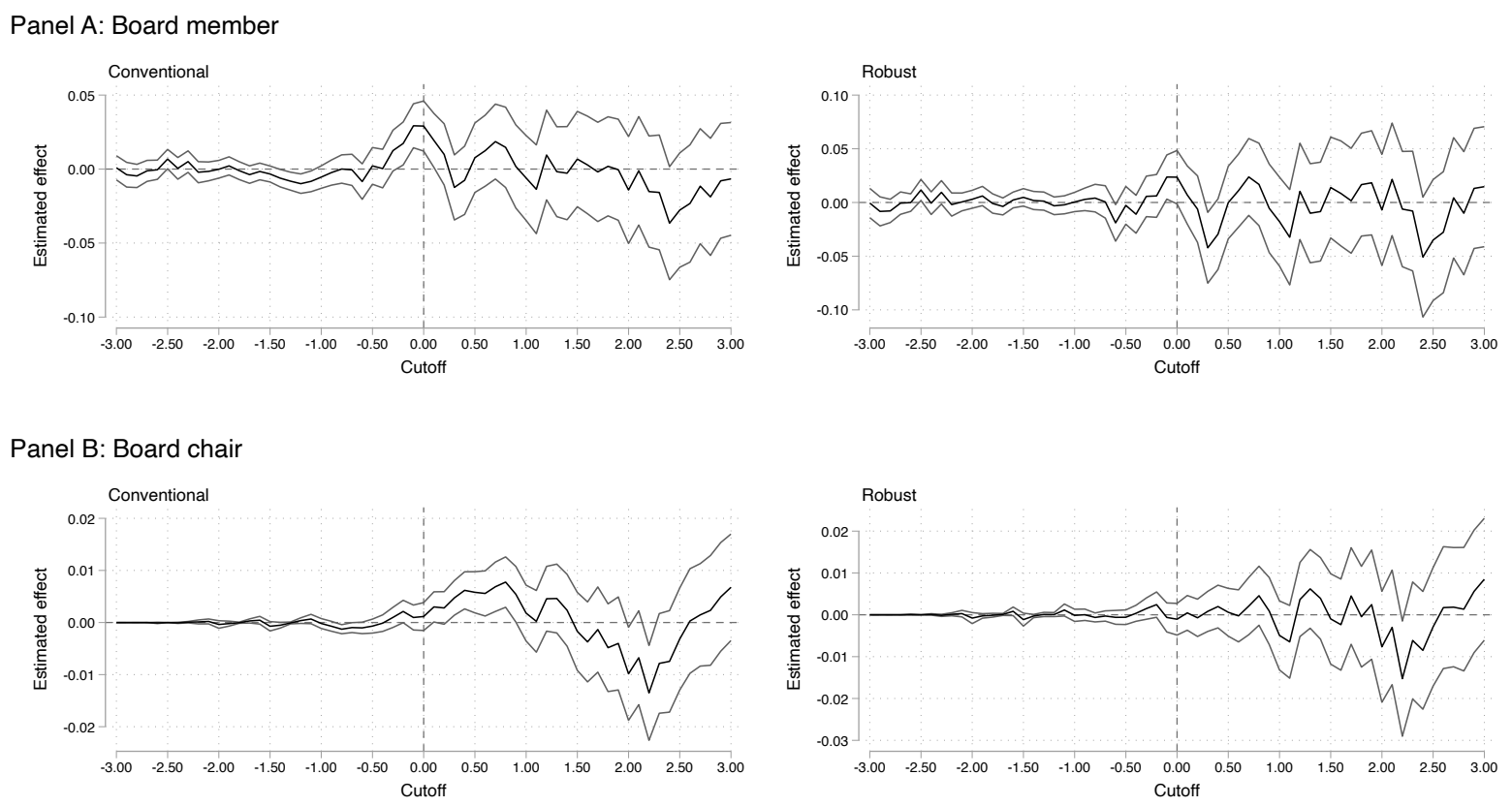

Figure B3. Regression discontinuity estimates obtained using placebo thresholds.

Notes: The figure shows point estimates and their $95 \%$ confidence intervals that are obtained using placebo thresholds. The confidence intervals are constructed using standard errors clustered at the municipality level. 


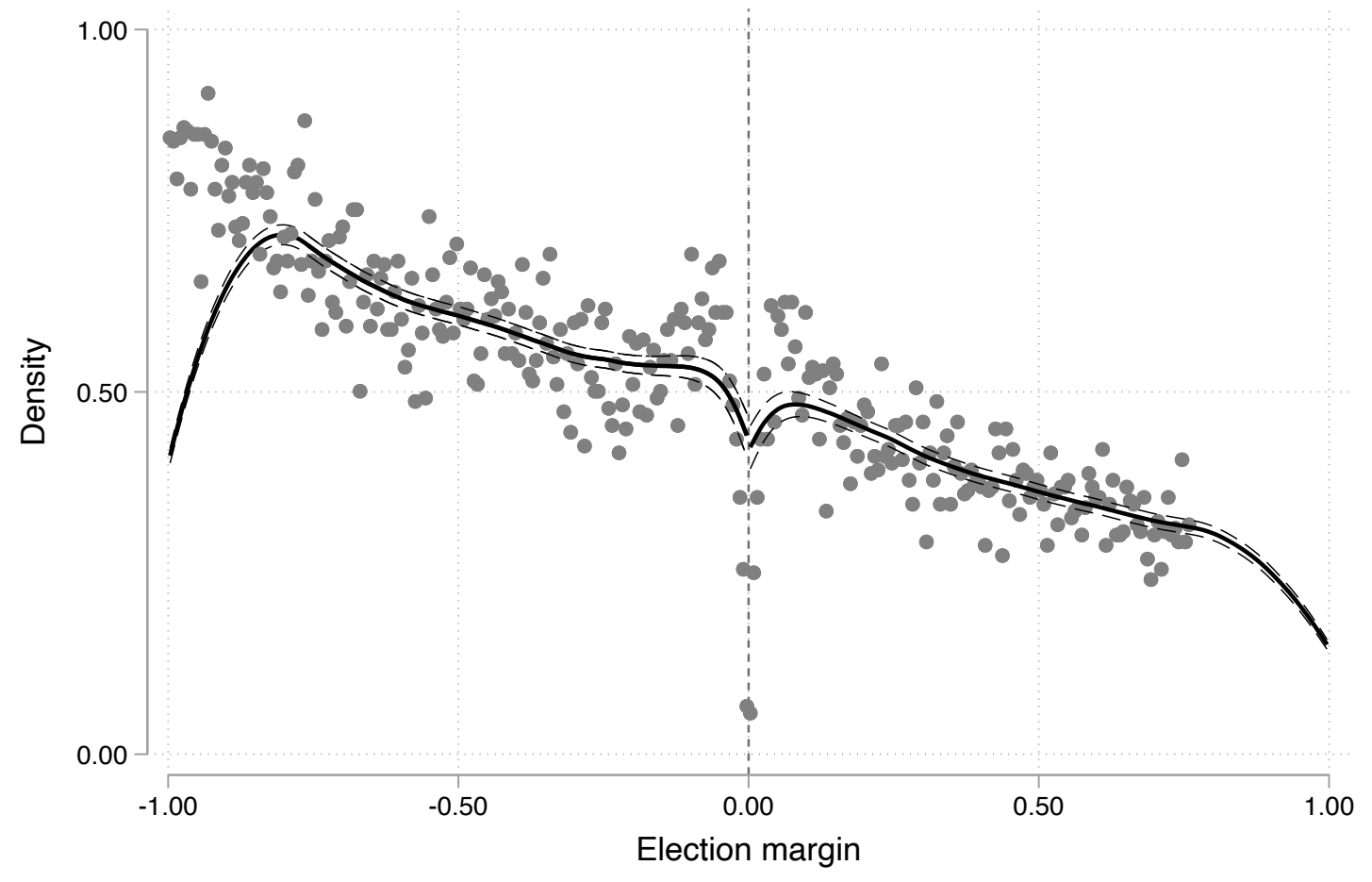

Figure B4. McCrary test.

Notes: The figure shows estimated density, its $95 \%$ confidence interval, and binned averages. There is no jump at the threshold. 


\section{Instrumental Variables Approach}

In this appendix, we provide additional information on the instrumental variables approach that we use in some of our analyses.

\section{C.1 Illustrative Example}

To illustrate how the instrumental variable for incumbents' seat share is constructed, consider the hypothetical example in Table C1. Suppose there is a party list with ten candidates, labeled with letters from $A$ to $J$. The vote shares of the candidates are as indicated in the table. We first identify the last elected and the first non-elected candidate. These are $E$ and $F$, respectively. We then fix the threshold for getting elected at $(7.03+7.03) / 2=7.03$. The closeness measure for each candidate is the difference between this threshold and their vote share. For instance, for candidate $D$ the closeness measure would get the value $7.59-7.03=0.56$.

For the sake of an example, let us say that the closeness measure that we have chosen is $\varepsilon=1$. All candidates for whom the absolute distance from the threshold for getting elected is $\varepsilon$ or less would be considered close. In this case, the close candidates would be $C, D, E, F$, and $G$. Let us further assume that candidates $E, F$, and $G$ are incumbents. We can now calculate how many incumbents we would have expect to elect in close elections. If getting elected is essentially a random draw for the candidates involved in close elections, we obtain this expected number using a hyper-geometric distribution. The expected number of incumbents elected in close elections would be $(3 / 5) \times 3=1.8$. However, only one incumbent was elected. By chance, less incumbents got elected than we would have expected in the close elections. The difference between the actual and expected number of elected incumbents is $1-1.8=-0.8$. Last, we multiply this by $100 / S_{m t}$ (where $S_{m t}$ is the council size in a municipality $m$ at time $t$ ) to obtain the instrument for incumbents' seat share. 
Table C1. Illustrative example.

\begin{tabular}{|c|c|c|c|c|c|}
\hline Candidate & Vote share & Closeness & Elected & Incumbent & Close \\
\hline A & 32.35 & 25.32 & 1 & 0 & 0 \\
\hline B & 25.60 & 18.57 & 1 & 1 & 0 \\
\hline $\mathrm{C}$ & 8.02 & 0.98 & 1 & 0 & 1 \\
\hline $\mathrm{D}$ & 7.59 & 0.56 & 1 & 0 & 1 \\
\hline $\mathrm{E}$ & 7.03 & 0.00 & 1 & 1 & 1 \\
\hline $\mathrm{F}$ & 7.03 & 0.00 & 0 & 1 & 1 \\
\hline G & 6.89 & -0.14 & 0 & 1 & 1 \\
\hline $\mathrm{H}$ & 3.09 & -3.94 & 0 & 0 & 0 \\
\hline I & 2.25 & -4.78 & 0 & 1 & 0 \\
\hline $\mathrm{J}$ & 0.14 & -6.89 & 0 & 1 & 0 \\
\hline \multicolumn{6}{|c|}{$\begin{array}{l}\text { Actual number of (re-)elected incumbents }=1 \\
\text { Expected number of (re-)elected incumbents }=(3 / 5) \times 3=1.8 \\
T_{p}=1-1.8=-0.8\end{array}$} \\
\hline
\end{tabular}




\section{C.2 Identifying Variation}

Figures $\mathrm{C} 1$ and $\mathrm{C} 2$ show the distribution of the instrumental variable (excluding and including zeros). We plot the distributions by party (for eight largest parties). We see that most of the identifying variation comes from the three largest parties: the Center Party, the National Coalition Party, and the Social Democratic Party. However, there is also some variation within the smaller party lists. 

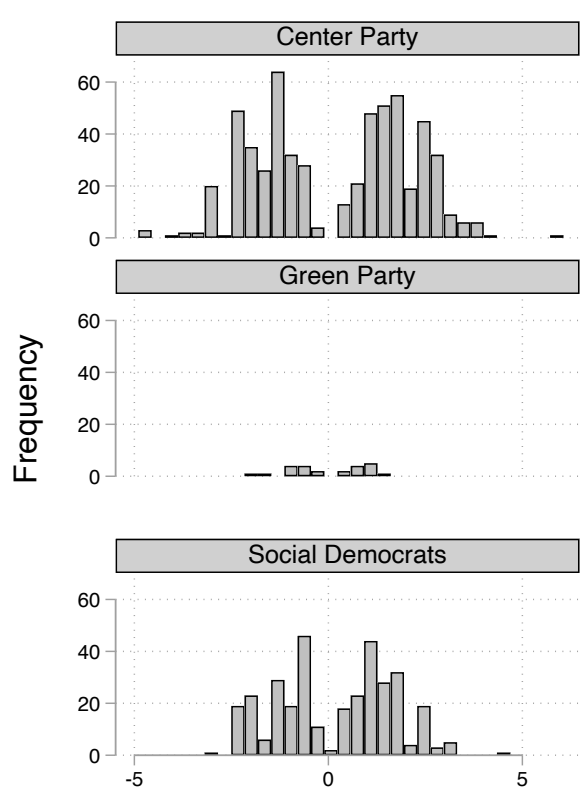

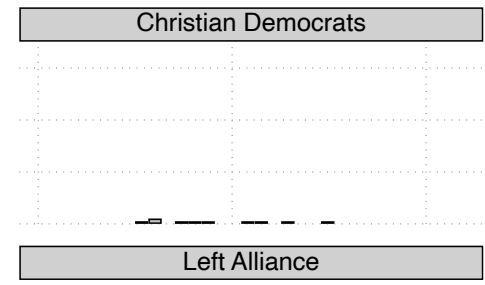

Left Alliance

- ITh +ाthr

Swedish Party

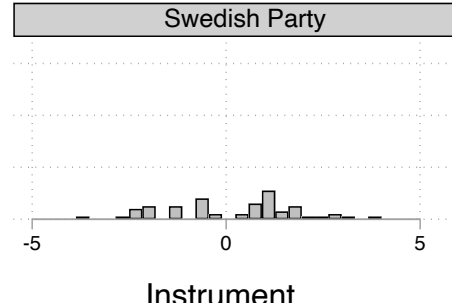

Finns Party

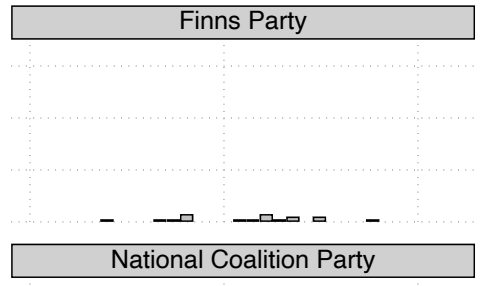

National Coalition Party

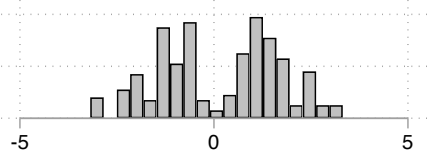

Figure C1. Identifying variation (zeros excluded).

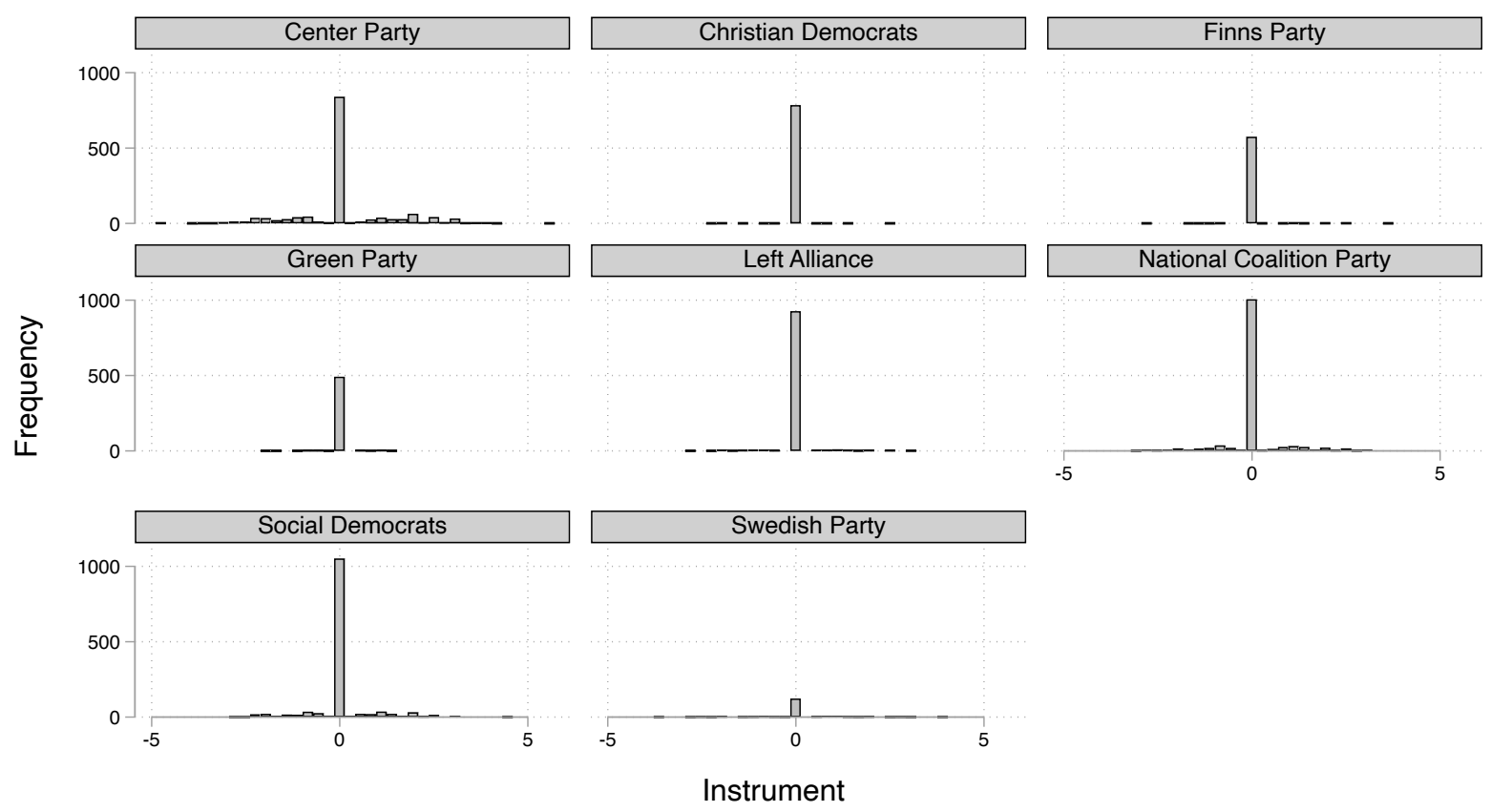

Figure C2. Identifying variation (zeros included). 


\section{C.3 Validity Checks}

In general, the seat share of re-elected incumbents strongly correlates with various party characteristics. We find that this is not the case when we limit our attention to the close elections. To demonstrate this, we report balance tests for different party characteristics using the same definition of electoral closeness as we use in our main analyses $(\varepsilon=0.2)$. We divide the data into two groups based on the seat share exceeding or falling short of its expected value in close elections, and then test for differences in means using a $t$-test adjusted for clustering at the municipality level. Tables C2 and C3 report the results from these analyses in the limited and the full sample, respectively. We do not find that parties that elect (by chance) more incumbents than expected would be different from those parties that elect less incumbents than expected. This is good news for the validity of our IV approach.

We also conduct a placebo threshold analysis. This test is analogous to the fake threshold test typically conducted in regression discontinuity design settings to show that there is a discontinuity only at the true cutoff. The results from this analysis can be found in Figure C3. For the first-stage placebo test (Panel A), we move the within-party threshold of getting elected by steps of 0.05 when constructing the instrument. We regress the actual seat share of incumbent politicians on the placebo instruments. As expected, the placebo results fluctuate around zero. Moreover, they are not systematically statistically significant. For the IV results (Panels B and C), the first stage has to be re-estimated. When the thresholds for getting elected are artificially changed, the council size and composition also change. Therefore, at each of the artificial thresholds, we compute the respective placebo council sizes, the seat shares of re-elected incumbents, and the instrument. We use the artificial seat share of incumbent politicians as the endogenous variable of interest instead of the real share, and instrument it with the placebo instrument. Using the placebo seat share ensures that the first stage of the placebo IV works as it should. This is because there is an approximate one-to-one relationship between the placebo seat share and the placebo instrument even at the fake thresholds. Again, we do not find any systematic effects at the fake thresholds. 
Table C2. Balance test (limited sample).

\begin{tabular}{lcccc}
\hline & Negative instrument & Positive instrument & Difference & $p$-value \\
\hline Seat share & 35.00 & 35.28 & 0.28 & 0.87 \\
Voting power & 42.64 & 43.17 & 0.53 & 0.86 \\
Women \% & 37.12 & 35.70 & -1.41 & 0.15 \\
Unemployed \% & 2.05 & 2.34 & 0.29 & 0.40 \\
Public employees \% & 22.92 & 23.08 & 0.16 & 0.88 \\
Entrepreneurs \% & 21.91 & 21.84 & -0.07 & 0.97 \\
High professionals \% & 27.24 & 26.59 & -0.65 & 0.69 \\
\hline
\end{tabular}

Notes: The table reports averages for municipalities with a negative or a positive instrument value. We also test for differences in means using a $t$-test adjusted for clustering at the municipality level.

Table C3. Balance test (full sample).

\begin{tabular}{lcccc}
\hline & Negative instrument & Positive instrument & Difference & $p$-value \\
\hline Seat share & 35.00 & 35.28 & 0.28 & 0.87 \\
Voting power & 42.64 & 43.17 & 0.53 & 0.86 \\
Women \% & 37.12 & 35.70 & -1.41 & 0.15 \\
Unemployed \% & 2.05 & 2.34 & 0.29 & 0.40 \\
Public employees \% & 22.92 & 23.08 & 0.16 & 0.88 \\
Entrepreneurs \% & 21.91 & 21.84 & -0.07 & 0.97 \\
High professionals \% & 27.24 & 26.59 & -0.65 & 0.69 \\
\hline
\end{tabular}

Notes: The table reports averages for municipalities with a negative or a positive instrument value. We also test for differences in means using a $t$-test adjusted for clustering at the municipality level. 

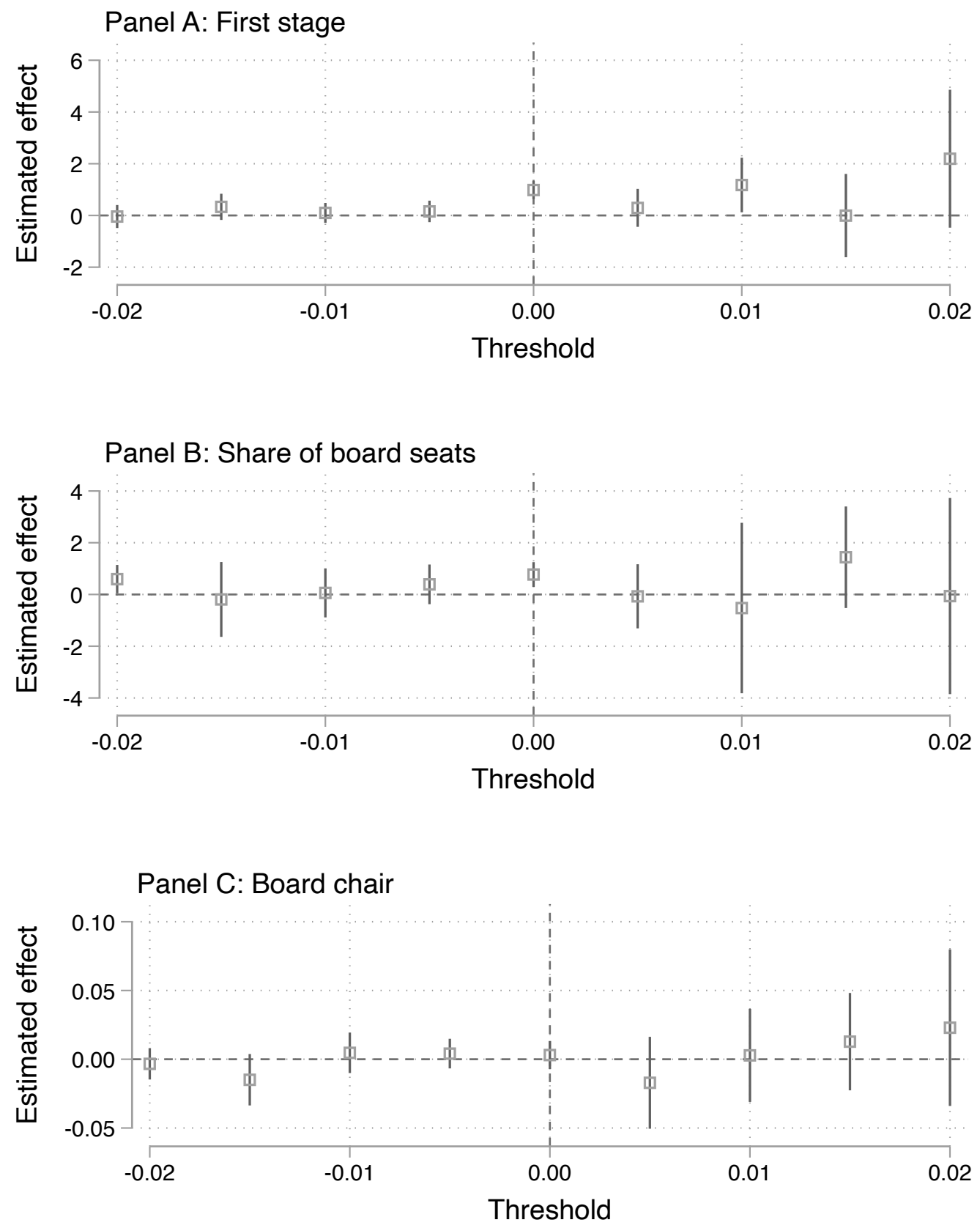

Figure C3. Placebo threshold test.

Notes: The figure shows point estimates and their 95\% confidence intervals (constructed based on standard errors that are clustered at the municipality level). 


\section{Robustness Checks: Party-Level Results}

This appendix presents a number of robustness checks for the party-level analyses.

\section{D.1 Robustness of the Main Results}

We start by assessing the robustness of our main results. First, we experiment with alternative controls for political power. The IV analyses that we present in the main text do not include any additional covariates as such are not needed for identification. If we control for the Shapley and Shubik (1954) index of voting power, our point estimates remain unchanged but we gain more statistical power (Table D1). Unfortunately, the same is not true if we control for the party council seat share (Table D2). The point estimates remain positive but are considerably smaller. We suspect that this finding may reflect the fact that once we net out party seat shares, we are left with considerably less variation that we can exploit. As a third measure of political power, we employ the Banzhaf power index (Penrose 1946). We find that both the OLS and IV results are robust to using this voting power metric (Table D3).

Second, we augment our estimations with municipality fixed effects (columns 1-4) or municipality-year fixed effects (columns 5-8) in Table D4. Recall that we only observe the board seat shares (the dependent variable in columns 1-4) for one electoral term, so we cannot include municipality-year fixed effects in the respective estimations, while we have data on board chairmen for multiple terms. Our qualitative conclusions remain unchanged after adding these controls.

Fourth, we evaluate the robustness of the IV and RF results for alternative definitions of electoral closeness in Figure D1. Consider first Panel A where we look at the share of board seats, and note that in order to keep the figure legible, we omit some of the very smallest bandwidths to avoid having extremely wide confidence intervals. We see that the magnitude of the estimates slowly gets smaller as we make the bandwidth more narrow. However, the confidence intervals also widen considerably, and the instrument loses its strength as we make the bandwidth more 
narrow. The point estimates are more stable in Panel B where we also have a larger number of observations available. While the regression coefficients are not statistically significant at any conventional levels, their magnitude remains unchanged throughout different definitions of closeness.

Finally, as we explain in the main text, close elections do not occur within all parties. For these observations, we have no meaningful variation in the instrumental variable. Dropping out such observations results in largely similar conclusions (see Table D5). Due to smaller sample sizes, however, the point estimates come with larger standard errors. 
Table D1. Political power, incumbents, and coalitional bargaining outcomes (controlling for Shapley-Shubik index).

\begin{tabular}{|c|c|c|c|c|}
\hline & \multicolumn{2}{|c|}{ Share of board seats } & \multicolumn{2}{|c|}{ Board chair } \\
\hline & (1) & (2) & (3) & (4) \\
\hline Voting power & $\begin{array}{c}0.429 * * * \\
(0.075)\end{array}$ & $\begin{array}{c}0.597 * * * \\
(0.012)\end{array}$ & $\begin{array}{c}0.009 * * * \\
(0.001)\end{array}$ & $\begin{array}{c}0.010 * * * \\
(0.000)\end{array}$ \\
\hline Incumbent seat share & $\begin{array}{c}0.502 * * \\
(0.217)\end{array}$ & & $\begin{array}{c}0.003 \\
(0.005)\end{array}$ & \\
\hline Instrument & & $\begin{array}{l}0.756 * \\
(0.400)\end{array}$ & & $\begin{array}{c}0.004 \\
(0.006)\end{array}$ \\
\hline Constant & $\begin{array}{c}4.904 * * * \\
(0.914)\end{array}$ & $\begin{array}{c}7.002 * * * \\
(0.268)\end{array}$ & $\begin{array}{c}-0.028 \\
(0.022)\end{array}$ & $\begin{array}{c}-0.013 * * * \\
(0.003)\end{array}$ \\
\hline Specification & IV & RF & IV & $\mathrm{RF}$ \\
\hline$N$ & 1803 & 1803 & 7636 & 7636 \\
\hline$R^{2}$ & 0.82 & 0.75 & 0.54 & 0.53 \\
\hline First stage $F$ & 29.11 & & 126.69 & \\
\hline Outcome mean & 17.98 & 17.98 & 0.19 & 0.19 \\
\hline
\end{tabular}

Notes: Standard errors clustered at the municipality level are reported in parentheses. $*, * *$ and $* * *$ denote statistical significance at $10 \%, 5 \%$ and $1 \%$, respectively. 
Table D2. Political power, incumbents, and coalitional bargaining outcomes (controlling for party seat share).

\begin{tabular}{|c|c|c|c|c|}
\hline & \multicolumn{2}{|c|}{ Share of board seats } & \multicolumn{2}{|c|}{ Board chair } \\
\hline & (1) & (2) & (3) & (4) \\
\hline Seat share & $\begin{array}{c}1.003 * * * \\
(0.129)\end{array}$ & $\begin{array}{c}1.036 * * * \\
(0.012)\end{array}$ & $\begin{array}{c}0.015^{* * * *} \\
(0.003)\end{array}$ & $\begin{array}{c}0.016 * * * \\
(0.000)\end{array}$ \\
\hline Incumbent seat share & $\begin{array}{c}0.057 \\
(0.215)\end{array}$ & & $\begin{array}{c}0.003 \\
(0.005)\end{array}$ & \\
\hline Instrument & & $\begin{array}{c}0.064 \\
(0.244)\end{array}$ & & $\begin{array}{c}0.003 \\
(0.006)\end{array}$ \\
\hline Constant & $\begin{array}{c}-1.023 * * * \\
(0.205)\end{array}$ & $\begin{array}{c}-1.038 * * * \\
(0.178)\end{array}$ & $\begin{array}{c}-0.128 * * * \\
(0.004)\end{array}$ & $\begin{array}{c}-0.128 * * * \\
(0.004)\end{array}$ \\
\hline Specification & IV & RF & IV & RF \\
\hline$N$ & 1803 & 1803 & 7636 & 7636 \\
\hline$R^{2}$ & 0.92 & 0.92 & 0.52 & 0.52 \\
\hline First stage $F$ & 31.29 & & 148.63 & \\
\hline Outcome mean & 17.98 & 17.98 & 0.19 & 0.19 \\
\hline
\end{tabular}

Notes: Standard errors clustered at the municipality level are reported in parentheses. $*, * *$ and $* * *$ denote statistical significance at $10 \%, 5 \%$ and $1 \%$, respectively. 
Table D3. Political power, incumbents, and coalitional bargaining outcomes (controlling for Banzhaf index).

\begin{tabular}{|c|c|c|c|c|c|c|}
\hline & \multicolumn{3}{|c|}{ Share of board seats } & \multicolumn{3}{|c|}{ Board chair } \\
\hline & (1) & (2) & (3) & (4) & (5) & (6) \\
\hline Voting power & $\begin{array}{c}0.252 * * * \\
(0.013)\end{array}$ & $\begin{array}{c}0.392 * * * \\
(0.069)\end{array}$ & $\begin{array}{c}0.521 * * * \\
(0.008)\end{array}$ & $\begin{array}{c}0.007 * * * \\
(0.000)\end{array}$ & $\begin{array}{c}0.008 * * * \\
(0.001)\end{array}$ & $\begin{array}{c}0.009 * * * \\
(0.000)\end{array}$ \\
\hline Incumbent seat share & $\begin{array}{c}0.917 * * * \\
(0.039)\end{array}$ & $\begin{array}{l}0.441 * \\
(0.231)\end{array}$ & & $\begin{array}{c}0.006^{* * * *} \\
(0.001)\end{array}$ & $\begin{array}{c}0.003 \\
(0.005)\end{array}$ & \\
\hline Instrument & & & $\begin{array}{c}0.624 \\
(0.393)\end{array}$ & & & $\begin{array}{c}0.004 \\
(0.005)\end{array}$ \\
\hline Constant & $\begin{array}{c}2.091 * * * \\
(0.231)\end{array}$ & $\begin{array}{c}3.514 * * * \\
(0.701)\end{array}$ & $\begin{array}{c}4.820 * * * \\
(0.313)\end{array}$ & $\begin{array}{c}-0.074 * * * \\
(0.003)\end{array}$ & $\begin{array}{c}-0.064 * * * \\
(0.017)\end{array}$ & $\begin{array}{c}-0.052 * * * \\
(0.004)\end{array}$ \\
\hline Specification & OLS & IV & RF & OLS & IV & RF \\
\hline$N$ & 1804 & 1804 & 1804 & 7647 & 7647 & 7647 \\
\hline$R^{2}$ & 0.85 & 0.82 & 0.76 & 0.55 & 0.55 & 0.54 \\
\hline First stage $F$ & & 25.40 & & & 97.36 & \\
\hline Outcome mean & 18.02 & 18.02 & 18.02 & 0.19 & 0.19 & 0.19 \\
\hline
\end{tabular}

Notes: Standard errors clustered at the municipality level are reported in parentheses. *, ** and $* * *$ denote statistical significance at $10 \%, 5 \%$ and $1 \%$, respectively. 
Table D4. Voting power, incumbents, and coalitional bargaining outcomes (fixed effects included).

\begin{tabular}{|c|c|c|c|c|c|c|c|c|}
\hline & \multicolumn{4}{|c|}{ Share of board seats } & \multicolumn{4}{|c|}{ Board chair } \\
\hline & (1) & (2) & (3) & (4) & (5) & (6) & (7) & (8) \\
\hline Voting power & $\begin{array}{c}0.246^{* * * *} \\
(0.016)\end{array}$ & & & & $\begin{array}{c}0.008 * * * \\
(0.000)\end{array}$ & & & \\
\hline Seat share & & $\begin{array}{c}0.988 * * * \\
(0.030)\end{array}$ & & & & $\begin{array}{c}0.017 * * * \\
(0.001)\end{array}$ & & \\
\hline Incumbent seat share & $\begin{array}{c}1.020 * * * \\
(0.038)\end{array}$ & $\begin{array}{c}0.111^{* * *} \\
(0.043)\end{array}$ & $\begin{array}{l}0.661^{*} \\
(0.365)\end{array}$ & & $\begin{array}{c}0.009 * * * \\
(0.001)\end{array}$ & $\begin{array}{c}0.001 \\
(0.001)\end{array}$ & $\begin{array}{c}0.016 * * * \\
(0.004)\end{array}$ & \\
\hline Instrument & & & & $\begin{array}{c}1.241 \\
(1.033)\end{array}$ & & & & $\begin{array}{c}0.031^{* * * *} \\
(0.011)\end{array}$ \\
\hline Constant & $\begin{array}{c}2.870^{* * * *} \\
(0.235)\end{array}$ & $\begin{array}{c}-1.313^{* * * *} \\
(0.209)\end{array}$ & & $\begin{array}{c}17.942 * * * \\
(0.032)\end{array}$ & $\begin{array}{c}-0.056^{* * * *} \\
(0.004)\end{array}$ & $\begin{array}{c}-0.147 * * * \\
(0.005)\end{array}$ & & $\begin{array}{c}0.187^{* * * *} \\
(0.000)\end{array}$ \\
\hline Specification & OLS & OLS & IV & RF & OLS & OLS & IV & RF \\
\hline$N$ & 1803 & 1803 & 1803 & 1803 & 7636 & 7636 & 7636 & 7636 \\
\hline$R^{2}$ & 0.86 & 0.93 & 0.54 & 0.09 & 0.55 & 0.54 & 0.39 & 0.03 \\
\hline First stage $F$ & & & 10.07 & & & & 54.69 & \\
\hline Outcome mean & 17.98 & 17.98 & 17.98 & 17.98 & 0.19 & 0.19 & 0.19 & 0.19 \\
\hline
\end{tabular}

Notes: Columns (1)-(4) use data from the 2009-2012 council term and control for municipality fixed effects. Columns (5)-(8) use data from the 2001-2016 council terms and control for municipality-year fixed effects. Standard errors clustered at the municipality level are reported in parentheses. $*, * *$ and $* * *$ denote statistical significance at $10 \%, 5 \%$ and $1 \%$, respectively.

Table D5. Voting power, incumbents, and coalitional bargaining outcomes (parties with no close elections excluded).

\begin{tabular}{|c|c|c|c|c|}
\hline & \multicolumn{2}{|c|}{ Share of board seats } & \multicolumn{2}{|c|}{ Board chair } \\
\hline & (1) & (2) & (3) & (4) \\
\hline Incumbent seat share & $\begin{array}{c}0.383 \\
(0.371)\end{array}$ & & $\begin{array}{c}0.008 \\
(0.005)\end{array}$ & \\
\hline Instrument & & $\begin{array}{c}0.535 \\
(0.636)\end{array}$ & & $\begin{array}{c}0.011 \\
(0.008)\end{array}$ \\
\hline Constant & $\begin{array}{c}24.987 * * * \\
(6.678)\end{array}$ & $\begin{array}{c}31.825 * * * \\
(0.755)\end{array}$ & $\begin{array}{c}0.277 * * * \\
(0.097)\end{array}$ & $\begin{array}{c}0.420 * * * \\
(0.010)\end{array}$ \\
\hline Specification & IV & $\mathrm{RF}$ & IV & $\mathrm{RF}$ \\
\hline$N$ & 605 & 605 & 2511 & 2511 \\
\hline$R^{2}$ & 0.35 & 0.00 & 0.17 & 0.00 \\
\hline First stage $F$ & 13.25 & & 60.22 & \\
\hline Outcome mean & 31.87 & 31.87 & 0.42 & 0.42 \\
\hline
\end{tabular}

Notes: Standard errors clustered at the municipality level are reported in parentheses. $*, * *$ and $* * *$ denote statistical significance at $10 \%$, $5 \%$ and $1 \%$, respectively. 

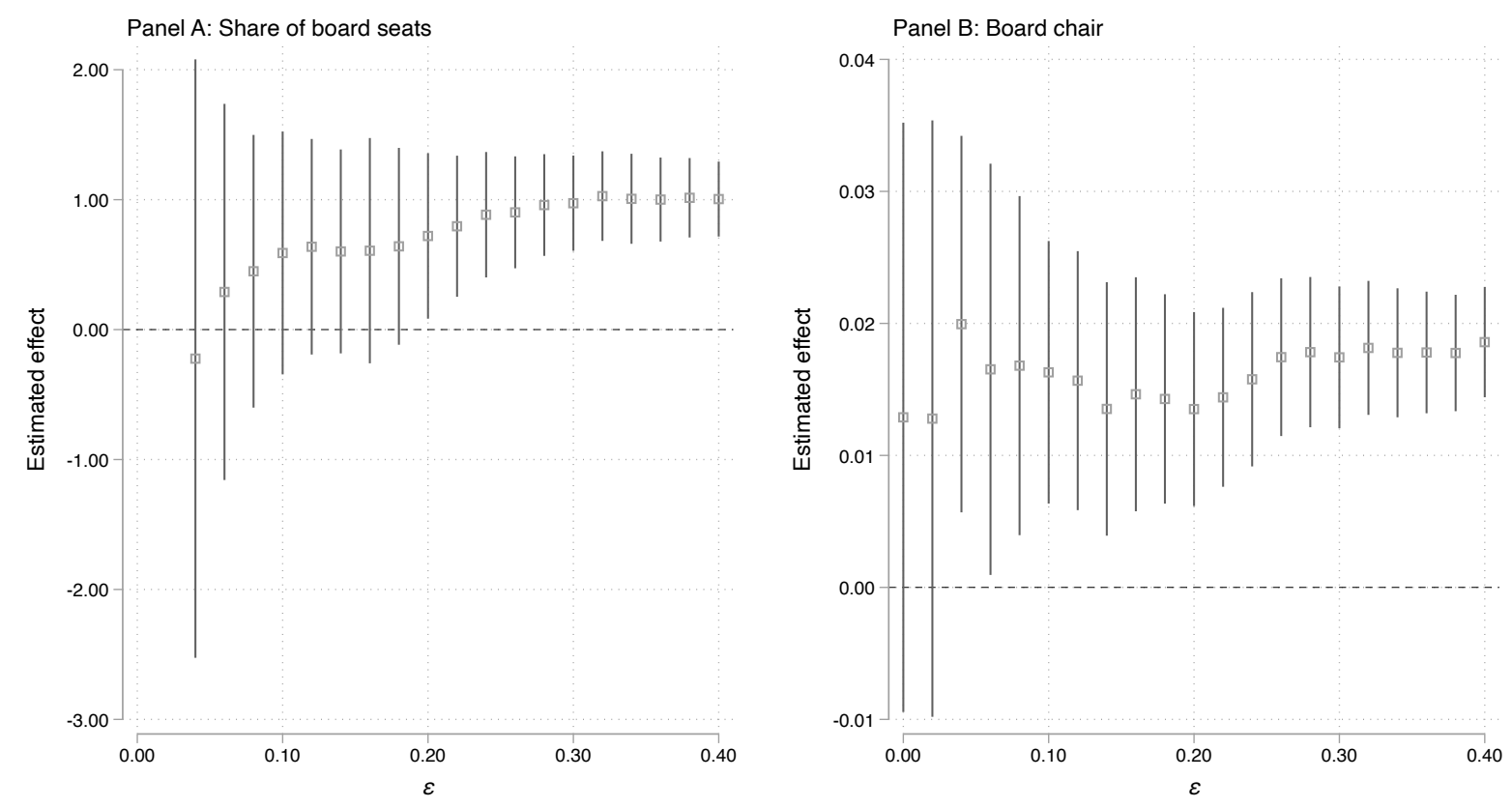

Figure D1. Robustness of the main IV results to alternative definitions of closeness.

Notes: The figure shows point estimates and their $95 \%$ confidence intervals that are obtained using alternative definitions of closeness. The confidence intervals are constructed using standard errors clustered at the municipality level. 


\section{D.2 Robustness of the Heterogeneity Analyses}

In this subsection, we present robustness checks for the descriptive analyses that investigate how the role of incumbents may depend on different party characteristics and the local political context. Tables D6, D7, D9, and D10 examine whether the findings are robust to controlling for party seat share or Banzhaf index of voting power instead of the Shapley-Shubik index. Although the exact magnitude of the point estimates and statistical significance varies depending on the specification, the conclusions from the estimation results echo the discussion in our main text. Furthermore, the results are robust to controlling for municipality (or municipality-year) fixed effects, as we demonstrate in Tables D8 and D11. 
Table D6. Interaction between incumbent representation and party-level characteristics (control for party seat share).

\begin{tabular}{|c|c|c|c|c|c|}
\hline & \multicolumn{4}{|c|}{ Share of board seats } & \multirow{2}{*}{$\frac{\text { Board chair }}{(5)}$} \\
\hline & (1) & (2) & (3) & (4) & \\
\hline Seat share & $\begin{array}{c}0.931 * * * \\
(0.029)\end{array}$ & $\begin{array}{l}1.256 * * * \\
(0.079)\end{array}$ & $\begin{array}{l}0.992 * * * \\
(0.028)\end{array}$ & $\begin{array}{l}1.256 * * * \\
(0.079)\end{array}$ & $\begin{array}{l}0.015 * * * \\
(0.001)\end{array}$ \\
\hline Incumbent seat share & $\begin{array}{c}0.243 * * * \\
(0.042)\end{array}$ & $\begin{array}{c}0.008 \\
(0.113)\end{array}$ & $\begin{array}{c}0.007 \\
(0.049)\end{array}$ & $\begin{array}{c}0.008 \\
(0.113)\end{array}$ & $\begin{array}{c}0.002 \\
(0.001)\end{array}$ \\
\hline Largest party & $\begin{array}{c}6.479 * * * \\
(1.229)\end{array}$ & $\begin{array}{c}5.553 \\
(4.134)\end{array}$ & & $\begin{array}{c}5.553 \\
(4.134)\end{array}$ & \\
\hline Incumbent seat share $\times$ Largest party & $\begin{array}{l}-0.279 * * * \\
(0.049)\end{array}$ & $\begin{array}{c}0.023 \\
(0.232)\end{array}$ & & $\begin{array}{c}0.023 \\
(0.232)\end{array}$ & \\
\hline Seat share ${ }^{2}$ & & $\begin{array}{c}-0.006^{* *} \\
(0.002)\end{array}$ & & $\begin{array}{c}-0.006 * * \\
(0.002)\end{array}$ & \\
\hline Incumbent seat share ${ }^{2}$ & & $\begin{array}{c}0.003 \\
(0.006)\end{array}$ & & $\begin{array}{c}0.003 \\
(0.006)\end{array}$ & \\
\hline Seat share $\times$ Largest party & & $\begin{array}{l}-0.240 \\
(0.206)\end{array}$ & & $\begin{array}{l}-0.240 \\
(0.206)\end{array}$ & \\
\hline Seat share ${ }^{2} \times$ Largest party & & $\begin{array}{c}0.004 \\
(0.003)\end{array}$ & & $\begin{array}{c}0.004 \\
(0.003)\end{array}$ & \\
\hline Incumbent seat share ${ }^{2} \times$ Largest party & & $\begin{array}{l}-0.002 \\
(0.007)\end{array}$ & & $\begin{array}{l}-0.002 \\
(0.007)\end{array}$ & \\
\hline Ideological distance & & $\begin{array}{l}-0.229 \\
(0.337)\end{array}$ & $\begin{array}{l}-1.129 * * * \\
(0.357)\end{array}$ & $\begin{array}{l}-0.229 \\
(0.337)\end{array}$ & $\begin{array}{l}-0.018 * * \\
(0.007)\end{array}$ \\
\hline Incumbent seat share $\times$ Ideological distance & & $\begin{array}{c}0.035 \\
(0.046)\end{array}$ & $\begin{array}{c}0.223 * * * \\
(0.046)\end{array}$ & $\begin{array}{c}0.035 \\
(0.046)\end{array}$ & $\begin{array}{l}-0.001 \\
(0.001)\end{array}$ \\
\hline Constant & $\begin{array}{c}-1.468^{* * * *} \\
(0.181)\end{array}$ & $\begin{array}{c}-2.669 * * * \\
(0.348)\end{array}$ & $\begin{array}{c}-0.817 * * * \\
(0.276)\end{array}$ & $\begin{array}{c}-2.669 * * * \\
(0.348)\end{array}$ & $\begin{array}{c}-0.112 * * * \\
(0.006)\end{array}$ \\
\hline$N$ & 1803 & 1799 & 1799 & 1799 & 7423 \\
\hline$R^{2}$ & 0.92 & 0.92 & 0.92 & 0.92 & 0.52 \\
\hline
\end{tabular}

Notes: Standard errors clustered at the municipality level are reported in parentheses. *,** and $* * *$ denote statistical significance at $10 \%, 5 \%$ and $1 \%$ levels, respectively. 
Table D7. Interaction between incumbent representation and party-level characteristics (control for alternative measure of voting power).

\begin{tabular}{|c|c|c|c|c|c|}
\hline & \multicolumn{4}{|c|}{ Share of board seats } & \multirow{2}{*}{$\frac{\text { Board chair }}{(5)}$} \\
\hline & (1) & (2) & (3) & (4) & \\
\hline Voting power & $\begin{array}{c}0.213 * * * \\
(0.013)\end{array}$ & $\begin{array}{c}0.086^{* *} \\
(0.035)\end{array}$ & $\begin{array}{c}0.249 * * * \\
(0.014)\end{array}$ & $\begin{array}{c}0.079 * * \\
(0.034)\end{array}$ & $\begin{array}{c}0.007 * * * \\
(0.000)\end{array}$ \\
\hline Incumbent seat share & $\begin{array}{l}1.071 * * * \\
(0.040)\end{array}$ & $\begin{array}{c}1.257 * * * \\
(0.092)\end{array}$ & $\begin{array}{c}0.900 * * * \\
(0.052)\end{array}$ & $\begin{array}{l}1.470 * * * \\
(0.102)\end{array}$ & $\begin{array}{c}0.007 * * * \\
(0.001)\end{array}$ \\
\hline Largest party & $\begin{array}{c}11.648 * * * \\
(1.353)\end{array}$ & $\begin{array}{c}48.077 * * * \\
(11.454)\end{array}$ & & $\begin{array}{c}47.321 * * * \\
(11.446)\end{array}$ & \\
\hline Incumbent seat share $\times$ Largest party & $\begin{array}{c}-0.426 * * * \\
(0.059)\end{array}$ & $\begin{array}{c}-1.202 * * * \\
(0.186)\end{array}$ & & $\begin{array}{c}-1.305^{* * *} \\
(0.190)\end{array}$ & \\
\hline Voting power ${ }^{2}$ & & $\begin{array}{l}0.001 * \\
(0.001)\end{array}$ & & $\begin{array}{l}0.001 * \\
(0.001)\end{array}$ & \\
\hline Incumbent seat share ${ }^{2}$ & & $\begin{array}{l}-0.005 \\
(0.005)\end{array}$ & & $\begin{array}{c}-0.008 * \\
(0.005)\end{array}$ & \\
\hline Voting power $\times$ Largest party & & $\begin{array}{c}-0.821 * * \\
(0.322)\end{array}$ & & $\begin{array}{c}-0.767 * * \\
(0.321)\end{array}$ & \\
\hline Voting power $^{2} \times$ Largest party & & $\begin{array}{c}0.006 * * * \\
(0.002)\end{array}$ & & $\begin{array}{c}0.006^{* *} \\
(0.002)\end{array}$ & \\
\hline Incumbent seat share ${ }^{2} \times$ Largest party & & $\begin{array}{l}0.010^{*} \\
(0.006)\end{array}$ & & $\begin{array}{c}0.012 * * \\
(0.006)\end{array}$ & \\
\hline Ideological distance & & & $\begin{array}{c}-1.272 * * * \\
(0.476)\end{array}$ & $\begin{array}{l}-0.114 \\
(0.434)\end{array}$ & $\begin{array}{l}-0.017 * * * \\
(0.006)\end{array}$ \\
\hline Incumbent seat share $\times$ Ideological distance & & & $\begin{array}{c}0.040 \\
(0.060)\end{array}$ & $\begin{array}{c}-0.217 * * * \\
(0.058)\end{array}$ & $\begin{array}{l}-0.000 \\
(0.001)\end{array}$ \\
\hline Constant & $\begin{array}{l}1.387 * * * \\
(0.233)\end{array}$ & $\begin{array}{l}1.659 * * * \\
(0.288)\end{array}$ & $\begin{array}{c}2.905 * * * \\
(0.363)\end{array}$ & $\begin{array}{c}1.687 * * * \\
(0.364)\end{array}$ & $\begin{array}{c}-0.060 * * * \\
(0.005)\end{array}$ \\
\hline$N$ & 1803 & 1803 & 1799 & 1799 & 7423 \\
\hline$R^{2}$ & 0.85 & 0.86 & 0.85 & 0.87 & 0.55 \\
\hline
\end{tabular}

Notes: Standard errors clustered at the municipality level are reported in parentheses. *, ** and $* * *$ denote statistical significance at $10 \%, 5 \%$ and $1 \%$ levels, respectively. 
Table D8. Interaction between incumbent representation and party-level characteristics (fixed effects included).

\begin{tabular}{|c|c|c|c|c|c|}
\hline & \multicolumn{4}{|c|}{ Share of board seats } & \multirow{2}{*}{$\frac{\text { Board chair }}{(5)}$} \\
\hline & (1) & (2) & (3) & (4) & \\
\hline Voting power & $\begin{array}{l}0.268 * * * \\
(0.017)\end{array}$ & $\begin{array}{l}0.711^{* * *} \\
(0.095)\end{array}$ & $\begin{array}{l}0.270 * * * \\
(0.018)\end{array}$ & $\begin{array}{c}0.699 * * * \\
(0.095)\end{array}$ & $\begin{array}{c}0.008 * * * \\
(0.000)\end{array}$ \\
\hline Incumbent seat share & $\begin{array}{c}1.176 * * * \\
(0.037)\end{array}$ & $\begin{array}{c}1.010 * * * \\
(0.116)\end{array}$ & $\begin{array}{l}0.829 * * * \\
(0.056)\end{array}$ & $\begin{array}{c}1.173 * * * \\
(0.131)\end{array}$ & $\begin{array}{c}0.005 * * * \\
(0.001)\end{array}$ \\
\hline Largest party & $\begin{array}{l}19.963 * * * \\
(1.241)\end{array}$ & $\begin{array}{l}22.251 * * * \\
(3.276)\end{array}$ & & $\begin{array}{c}23.643 * * * \\
(3.443)\end{array}$ & \\
\hline Incumbent seat share $\times$ Largest party & $\begin{array}{c}-0.861 * * * \\
(0.059)\end{array}$ & $\begin{array}{c}-1.030 * * * \\
(0.193)\end{array}$ & & $\begin{array}{c}-1.134 * * * \\
(0.200)\end{array}$ & \\
\hline Voting power ${ }^{2}$ & & $\begin{array}{c}-0.012 * * * \\
(0.003)\end{array}$ & & $\begin{array}{c}-0.012 * * * \\
(0.003)\end{array}$ & \\
\hline Incumbent seat share ${ }^{2}$ & & $\begin{array}{c}0.004 \\
(0.006)\end{array}$ & & $\begin{array}{c}0.001 \\
(0.006)\end{array}$ & \\
\hline Voting power $\times$ Largest party & & $\begin{array}{c}-0.296^{* *} \\
(0.144)\end{array}$ & & $\begin{array}{c}-0.309 * * \\
(0.145)\end{array}$ & \\
\hline Voting power $^{2} \times$ Largest party & & $\begin{array}{c}0.011 * * * \\
(0.003)\end{array}$ & & $\begin{array}{c}0.011 * * * \\
(0.003)\end{array}$ & \\
\hline Incumbent seat share ${ }^{2} \times$ Largest party & & $\begin{array}{c}0.002 \\
(0.007)\end{array}$ & & $\begin{array}{c}0.005 \\
(0.007)\end{array}$ & \\
\hline Ideological distance & & & $\begin{array}{c}-3.023 * * * \\
(0.497)\end{array}$ & $\begin{array}{l}-0.502 \\
(0.479)\end{array}$ & $\begin{array}{c}-0.058 * * * \\
(0.007)\end{array}$ \\
\hline Incumbent seat share $\times$ Ideological distance & & & $\begin{array}{c}0.371^{* * *} \\
(0.065)\end{array}$ & $\begin{array}{c}-0.147 * * \\
(0.068)\end{array}$ & $\begin{array}{c}0.007 * * * \\
(0.002)\end{array}$ \\
\hline Constant & $\begin{array}{c}1.337 * * * \\
(0.227)\end{array}$ & $\begin{array}{c}0.460 \\
(0.282)\end{array}$ & $\begin{array}{l}4.257 * * * \\
(0.357)\end{array}$ & $\begin{array}{l}0.706^{*} \\
(0.384)\end{array}$ & $\begin{array}{l}-0.028 * * * \\
(0.006)\end{array}$ \\
\hline$N$ & 1803 & 1803 & 1799 & 1799 & 7419 \\
\hline$R^{2}$ & 0.89 & 0.89 & 0.87 & 0.89 & 0.56 \\
\hline
\end{tabular}

Notes: Standard errors clustered at the municipality level are reported in parentheses. Columns (1)-(3) control for municipality fixed effects, and column (4) controls for municipality-year fixed effects. *, ** and *** denote statistical significance at $10 \%, 5 \%$ and $1 \%$ levels, respectively. 


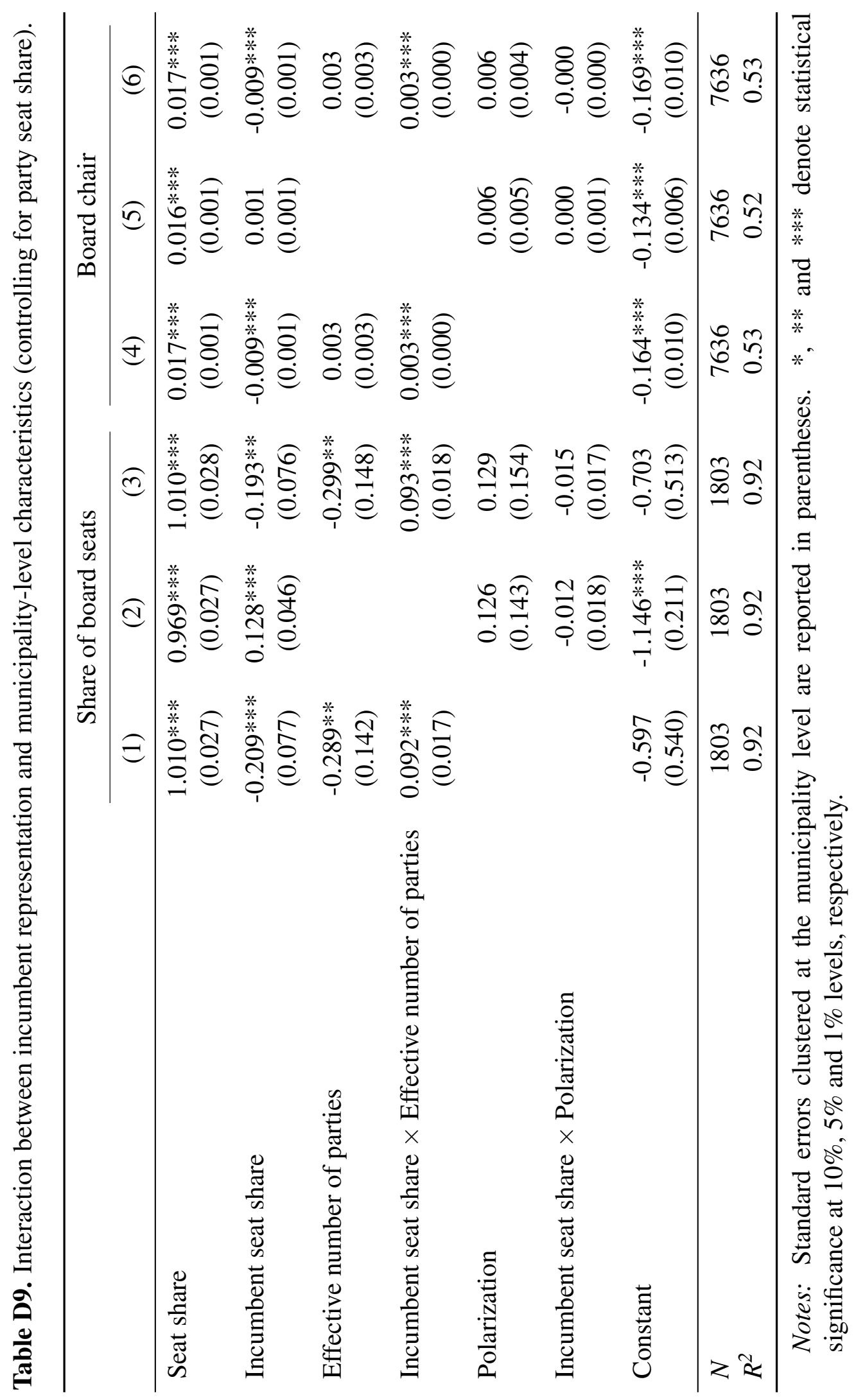




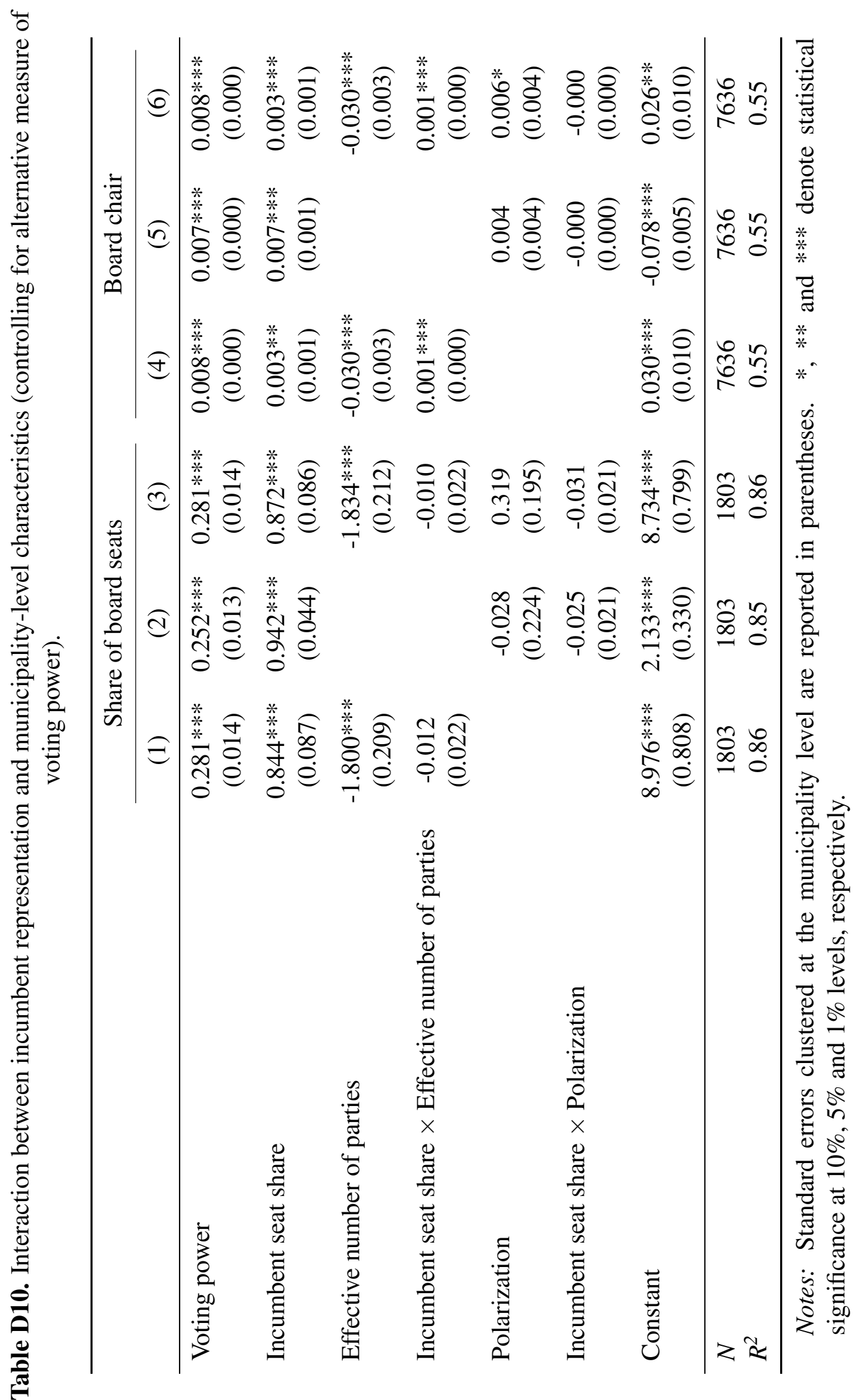




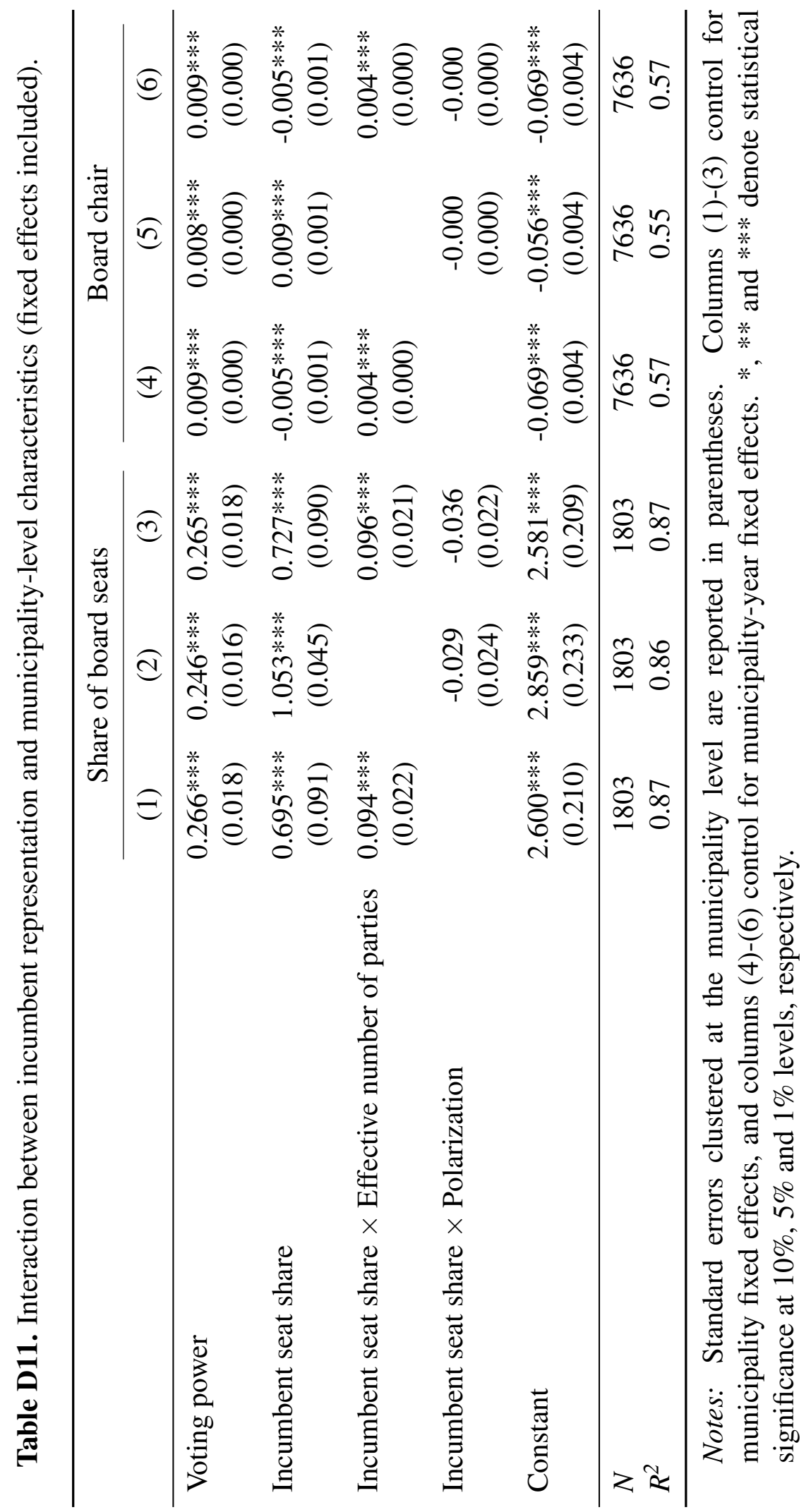

OA-33 


\section{E Implications for Selection}

Who benefits from incumbent representation in the council? In this appendix, we estimate the same models as before but decompose the dependent variable in two parts: incumbents' and nonincumbents' share of board seats. We plot the estimation results from four different specifications in Figure E1. Panel A shows that electing more incumbents instead of non-incumbents in the local council leads to more incumbents getting seats in the municipal board. The OLS result suggests that increasing incumbents' seat share by one percentage points is associated with an increase of around one percentage points in the share of board seats that a party obtains, no matter whether we control for voting power or party seat share. The 2SLS IV and reduced form of IV estimates suggest a slightly more moderate effect, around 0.58 and 0.88 , respectively.

Panel B reveals that there is no spill-over effect to non-incumbents. We also do not find any evidence of a crowding out effect, although the OLS estimate suggests a negative correlation between incumbent representation in the municipal council and non-incumbent representation in the municipal board.

We also asses the robustness of these selection results. Our results do not change much if we control for voting power measured by the Shapley-Shubik index (Table E1). But as before, if we control for party seat share, our point estimates lose statistical significance and also become smaller (Table E2). We have also tried controlling for the Banzhaf index of voting power instead of the Shapley-Shubik index (Table E3). The choice of voting power index does not seem to make a big difference. Similarly, the findings are robust to controlling for municipality fixed effects (Table E4), using alternative definitions of electoral closeness (Figure E2), or restricting the sample to include only parties that have close elections (Table E5). 

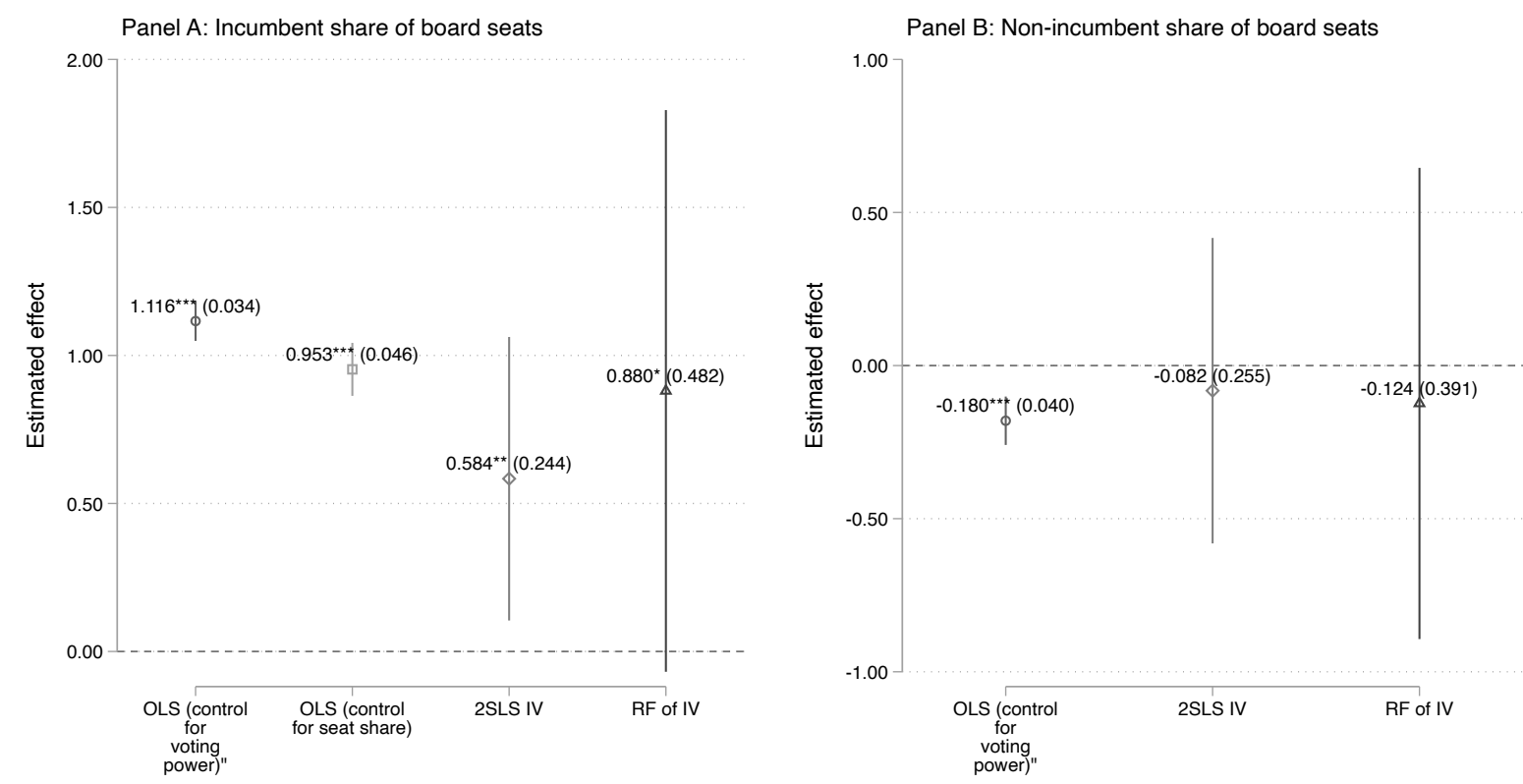

$N=1803$, First-stage $F=29.11$

Figure E1. The effect of incumbents on board composition.

Notes: The figure shows point estimates and their $95 \%$ confidence intervals constructed using standard errors clustered at the municipality level. *,** and $* * *$ denote statistical significance at $10 \%, 5 \%$ and $1 \%$ levels, respectively. 
Table E1. Effect of incumbent representation in the local council on incumbent and nonincumbent representation in the municipal board (controlling for Shapley-Shubik index).

\begin{tabular}{|c|c|c|c|c|}
\hline & \multicolumn{2}{|c|}{ Incumbent share of board seats } & \multicolumn{2}{|c|}{ Non-incumbent share of board seats } \\
\hline & (1) & (2) & (3) & (4) \\
\hline Voting power & $\begin{array}{c}0.193 * * \\
(0.085)\end{array}$ & $\begin{array}{c}0.389 * * * \\
(0.014)\end{array}$ & $\begin{array}{c}0.240 * * * \\
(0.089)\end{array}$ & $\begin{array}{c}0.210 * * * \\
(0.011)\end{array}$ \\
\hline Incumbent seat share & $\begin{array}{c}0.581 * * \\
(0.250)\end{array}$ & & $\begin{array}{c}-0.090 \\
(0.260)\end{array}$ & \\
\hline Instrument & & $\begin{array}{c}0.855 * \\
(0.482)\end{array}$ & & $\begin{array}{c}-0.133 \\
(0.390)\end{array}$ \\
\hline Constant & $\begin{array}{c}2.492^{* *} \\
(1.060)\end{array}$ & $\begin{array}{c}4.914 * * * \\
(0.238)\end{array}$ & $\begin{array}{c}2.451 * * \\
(1.102)\end{array}$ & $\begin{array}{c}2.075 * * * \\
(0.204)\end{array}$ \\
\hline Specification & IV & $\mathrm{RF}$ & IV & $\mathrm{RF}$ \\
\hline$N$ & 1804 & 1804 & 1804 & 1804 \\
\hline$R^{2}$ & 0.71 & 0.55 & 0.36 & 0.35 \\
\hline First stage $F$ & 27.20 & & 27.20 & \\
\hline Outcome mean & 12.09 & 12.09 & 5.93 & 5.93 \\
\hline
\end{tabular}

Notes: Standard errors clustered at the municipality level are reported in parentheses. *, ** and $* * *$ denote statistical significance at $10 \%, 5 \%$ and $1 \%$, respectively. 
Table E2. Effect of incumbent representation in the local council on incumbent and nonincumbent representation in the municipal board (controlling for party seat share).

\begin{tabular}{|c|c|c|c|c|}
\hline & \multicolumn{2}{|c|}{ Incumbent share of board seats } & \multicolumn{2}{|c|}{ Non-incumbent share of board seats } \\
\hline & (1) & (2) & (3) & (4) \\
\hline Seat share & $\begin{array}{c}0.456 * * \\
(0.191)\end{array}$ & $\begin{array}{c}0.681 * * * \\
(0.017)\end{array}$ & $\begin{array}{c}0.528 * * * \\
(0.182)\end{array}$ & $\begin{array}{c}0.352 * * * \\
(0.016)\end{array}$ \\
\hline Incumbent seat share & $\begin{array}{c}0.389 \\
(0.326)\end{array}$ & & $\begin{array}{l}-0.305 \\
(0.314)\end{array}$ & \\
\hline Instrument & & $\begin{array}{c}0.436 \\
(0.416)\end{array}$ & & $\begin{array}{c}-0.342 \\
(0.387)\end{array}$ \\
\hline Constant & $\begin{array}{c}-0.358 \\
(0.238)\end{array}$ & $\begin{array}{c}-0.460 * \\
(0.238)\end{array}$ & $\begin{array}{c}-0.616 * * * \\
(0.230)\end{array}$ & $\begin{array}{c}-0.536 * * \\
(0.233)\end{array}$ \\
\hline Specification & IV & $\mathrm{RF}$ & IV & $\mathrm{RF}$ \\
\hline$N$ & 1804 & 1804 & 1804 & 1804 \\
\hline$R^{2}$ & 0.74 & 0.68 & 0.49 & 0.40 \\
\hline First stage $F$ & 31.28 & & 31.28 & \\
\hline Outcome mean & 12.09 & 12.09 & 5.93 & 5.93 \\
\hline
\end{tabular}

Notes: Standard errors clustered at the municipality level are reported in parentheses. *, ** and $* * *$ denote statistical significance at $10 \%, 5 \%$ and $1 \%$, respectively. 
Table E3. Effect of incumbent representation in the local council on incumbent and nonincumbent representation in the municipal board (controlling for Banzhaf index).

\begin{tabular}{|c|c|c|c|c|c|c|}
\hline & \multicolumn{3}{|c|}{ Incumbent share of board seats } & \multicolumn{3}{|c|}{ Non-incumbent share of board seats } \\
\hline & (1) & (2) & (3) & (4) & (5) & (6) \\
\hline Voting power & $\begin{array}{c}0.043 * * * \\
(0.013)\end{array}$ & $\begin{array}{c}0.186 * * \\
(0.076)\end{array}$ & $\begin{array}{c}0.347 * * * \\
(0.010)\end{array}$ & $\begin{array}{c}0.209 * * * \\
(0.015)\end{array}$ & $\begin{array}{c}0.206 * * \\
(0.081)\end{array}$ & $\begin{array}{c}0.174 * * * \\
(0.009)\end{array}$ \\
\hline Incumbent seat share & $\begin{array}{c}1.037 * * * \\
(0.035)\end{array}$ & $\begin{array}{c}0.552 * * \\
(0.259)\end{array}$ & & $\begin{array}{c}-0.120 * * * \\
(0.039)\end{array}$ & $\begin{array}{l}-0.111 \\
(0.274)\end{array}$ & \\
\hline Instrument & & & $\begin{array}{l}0.782 * \\
(0.473)\end{array}$ & & & $\begin{array}{l}-0.158 \\
(0.396)\end{array}$ \\
\hline Constant & $\begin{array}{c}0.201 \\
(0.177)\end{array}$ & $\begin{array}{c}1.650 * * \\
(0.791)\end{array}$ & $\begin{array}{c}3.286^{* * * *} \\
(0.261)\end{array}$ & $\begin{array}{c}1.890 * * * \\
(0.233)\end{array}$ & $\begin{array}{c}1.864 * * \\
(0.835)\end{array}$ & $\begin{array}{c}1.534 * * * \\
(0.209)\end{array}$ \\
\hline Specification & OLS & IV & RF & OLS & IV & $\mathrm{RF}$ \\
\hline$N$ & 1804 & 1804 & 1804 & 1804 & 1804 & 1804 \\
\hline$R^{2}$ & 0.77 & 0.72 & 0.58 & 0.33 & 0.33 & 0.32 \\
\hline First stage $F$ & & 25.40 & & & 25.40 & \\
\hline Outcome mean & 12.09 & 12.09 & 12.09 & 5.93 & 5.93 & 5.93 \\
\hline
\end{tabular}

Notes: Standard errors clustered at the municipality level are reported in parentheses. *,** and $* * *$ denote statistical significance at $10 \%, 5 \%$ and $1 \%$, respectively. 
Table E4. Effect of incumbent representation in the local council on incumbent and nonincumbent representation in the municipal board (fixed effects included).

\begin{tabular}{|c|c|c|c|c|c|c|c|c|}
\hline & \multicolumn{4}{|c|}{ Incumbent share of board seats } & \multicolumn{4}{|c|}{ Non-incumbent share of board seats } \\
\hline & (1) & (2) & (3) & (4) & (5) & (6) & (7) & (8) \\
\hline Voting power & $\begin{array}{c}0.004 \\
(0.015)\end{array}$ & & & & $\begin{array}{c}0.242 * * * \\
(0.018)\end{array}$ & & & \\
\hline Seat share & & $\begin{array}{c}0.173 * * * \\
(0.035)\end{array}$ & & & & $\begin{array}{c}0.815 * * * \\
(0.033)\end{array}$ & & \\
\hline Incumbent seat share & $\begin{array}{c}1.162 * * * \\
(0.034)\end{array}$ & $\begin{array}{c}0.919 * * * \\
(0.048)\end{array}$ & $\begin{array}{c}0.666^{* * * *} \\
(0.228)\end{array}$ & & $\begin{array}{c}-0.142 * * * \\
(0.039)\end{array}$ & $\begin{array}{c}-0.808 * * * \\
(0.046)\end{array}$ & $\begin{array}{l}-0.005 \\
(0.278)\end{array}$ & \\
\hline Instrument & & & & $\begin{array}{l}1.250^{*} \\
(0.755)\end{array}$ & & & & $\begin{array}{l}-0.009 \\
(0.521)\end{array}$ \\
\hline Constant & $\begin{array}{l}-0.074 \\
(0.204)\end{array}$ & $\begin{array}{c}-0.649^{* *} \\
(0.268)\end{array}$ & & $\begin{array}{c}12.026^{* * * *} \\
(0.023)\end{array}$ & $\begin{array}{c}2.944 * * * \\
(0.226)\end{array}$ & $\begin{array}{c}-0.664 * * * \\
(0.254)\end{array}$ & & $\begin{array}{c}5.916^{* * * *} \\
(0.016)\end{array}$ \\
\hline Specification & OLS & OLS & IV & $\mathrm{RF}$ & OLS & OLS & IV & $\mathrm{RF}$ \\
\hline$N$ & 1803 & 1803 & 1803 & 1803 & 1803 & 1803 & 1803 & 1803 \\
\hline$R^{2}$ & 0.81 & 0.81 & 0.64 & 0.10 & 0.51 & 0.63 & -0.01 & 0.21 \\
\hline First stage $F$ & & & 10.07 & & & & 10.07 & \\
\hline Outcome mean & 12.06 & 12.06 & 12.06 & 12.06 & 5.92 & 5.92 & 5.92 & 5.92 \\
\hline
\end{tabular}

Notes: Columns (1)-(4) use data from the 2009-2012 council term and control for municipality fixed effects. Columns (5)-(8) use data from the 2001-2016 council terms and control for municipality and year fixed effects. Standard errors clustered at the municipality level are reported in parentheses. *, ** and $* * *$ denote statistical significance at $10 \%, 5 \%$ and $1 \%$, respectively.

Table E5. Effect of incumbent representation in the local council on incumbent and nonincumbent representation in the municipal board (parties with no close elections excluded).

\begin{tabular}{lccccc}
\hline & \multicolumn{2}{l}{ Incumbent share of board seats } & & \multicolumn{2}{c}{ Non-incumbent share of board seats } \\
\cline { 2 - 3 } \cline { 5 - 6 } & $(1)$ & $(2)$ & & $(3)$ & $(4)$ \\
\cline { 1 - 1 } Incumbent seat share & $0.497^{*}$ & & -0.114 & \\
& $(0.285)$ & & & $(0.335)$ & \\
Instrument & & 0.695 & & -0.159 \\
& & $(0.540)$ & & $(0.459)$ \\
Constant & $12.920^{* *}$ & $21.792^{* * *}$ & & $12.067^{* *}$ & $10.033^{* * *}$ \\
& $(5.111)$ & $(0.584)$ & & $(6.048)$ & $(0.500)$ \\
\hline Specification & $\mathrm{IV}$ & $\mathrm{RF}$ & & $\mathrm{IV}$ & $\mathrm{RF}$ \\
$N$ & 605 & 605 & & 605 & 605 \\
$R^{2}$ & 0.47 & 0.00 & & -0.07 & 0.00 \\
First stage $F$ & 13.25 & & & 13.25 & \\
Outcome mean & 21.86 & 21.86 & & 10.02 & 10.02 \\
\hline
\end{tabular}

Notes: Standard errors clustered at the municipality level are reported in parentheses. *, ** and $* * *$ denote statistical significance at $10 \%, 5 \%$ and $1 \%$, respectively. 

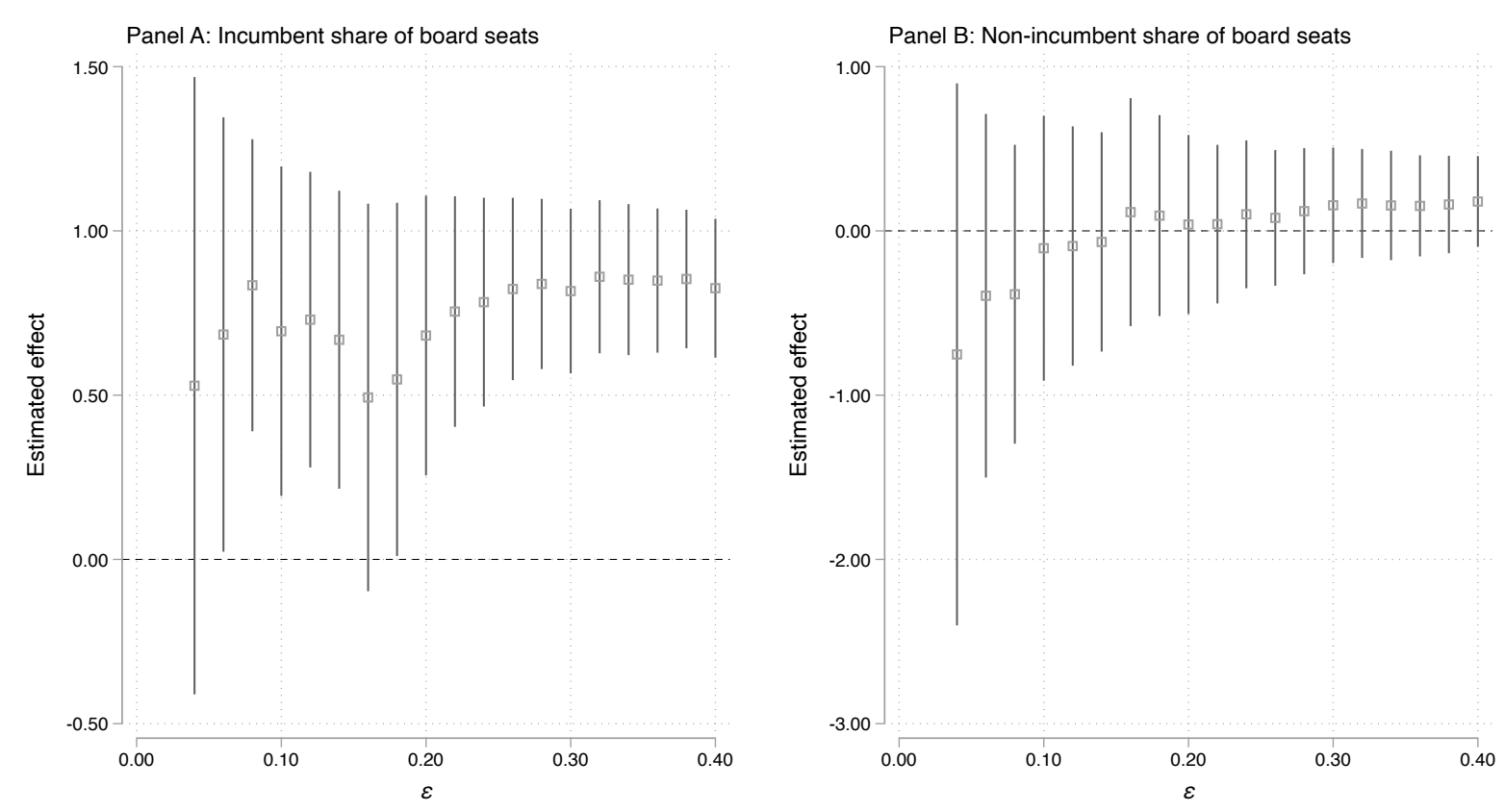

Figure E2. Effect of incumbent representation in the local council on incumbent and nonincumbent representation in the municipal board: robustness to alternative definitions of closeness.

Notes: The figure shows point estimates and their $95 \%$ confidence intervals that are obtained using alternative definitions of closeness. The confidence intervals are constructed using standard errors clustered at the municipality level. 


\section{F External Validity}

Does a similar pattern arise also in other contexts? As a first step towards understanding the generalizability of our argument and empirical findings, we have collected data on parties and the allocation of minister positions in three countries: Finland, Norway, and Ireland.

The Finnish data cover six elections between 1999-2019 and the corresponding government cabinets (at the beginning of the electoral term). We also combine data from Fiva and Smith (2017) and Cox et al. (2021) to assess whether incumbents could benefit parties in Norwegian national politics. These data yield a sample that contains eleven multiparty cabinets between the years 1961 and 2009. They allow us to compute the incumbent seat share, political power (seat share or voting power), and share of cabinet portfolios of each party. To compute the portfolio shares, we use information on all individuals who were ministers during an electoral term. Last, we borrow data from Smith and Martin (2017) on the selection of cabinet ministers in Ireland. Their candidate-level data cover Irish parliamentary elections and cabinets in 1944-2016. After excluding single-party governments, we end up with data from twelve cabinets. Again, the cabinet portfolio shares are based on information on all individuals who held a minister position during an electoral term.

Using these data, we use OLS to estimate our baseline specification that includes the incumbent seat share and a control for either voting power or party seat share. We only include parties that are part of the governing coalition to ensure maximal comparability with our main analyses. We illustrate our findings graphically in Figure F1, where the left-hand-side graphs include a control for voting power, and the right-hand-side figures include a control for party seat share. Although the sample size is rather small, our descriptive analysis provides encouraging evidence that an incumbency advantage may be present in coalitional bargaining more generally. Seven out of eight

specifications (two specifications per country and two specifications using pooled data) suggest a positive relationship between incumbent representation after controlling for party voting power or seat share, and this relationship is statistically significant in five out of eight specifications. 

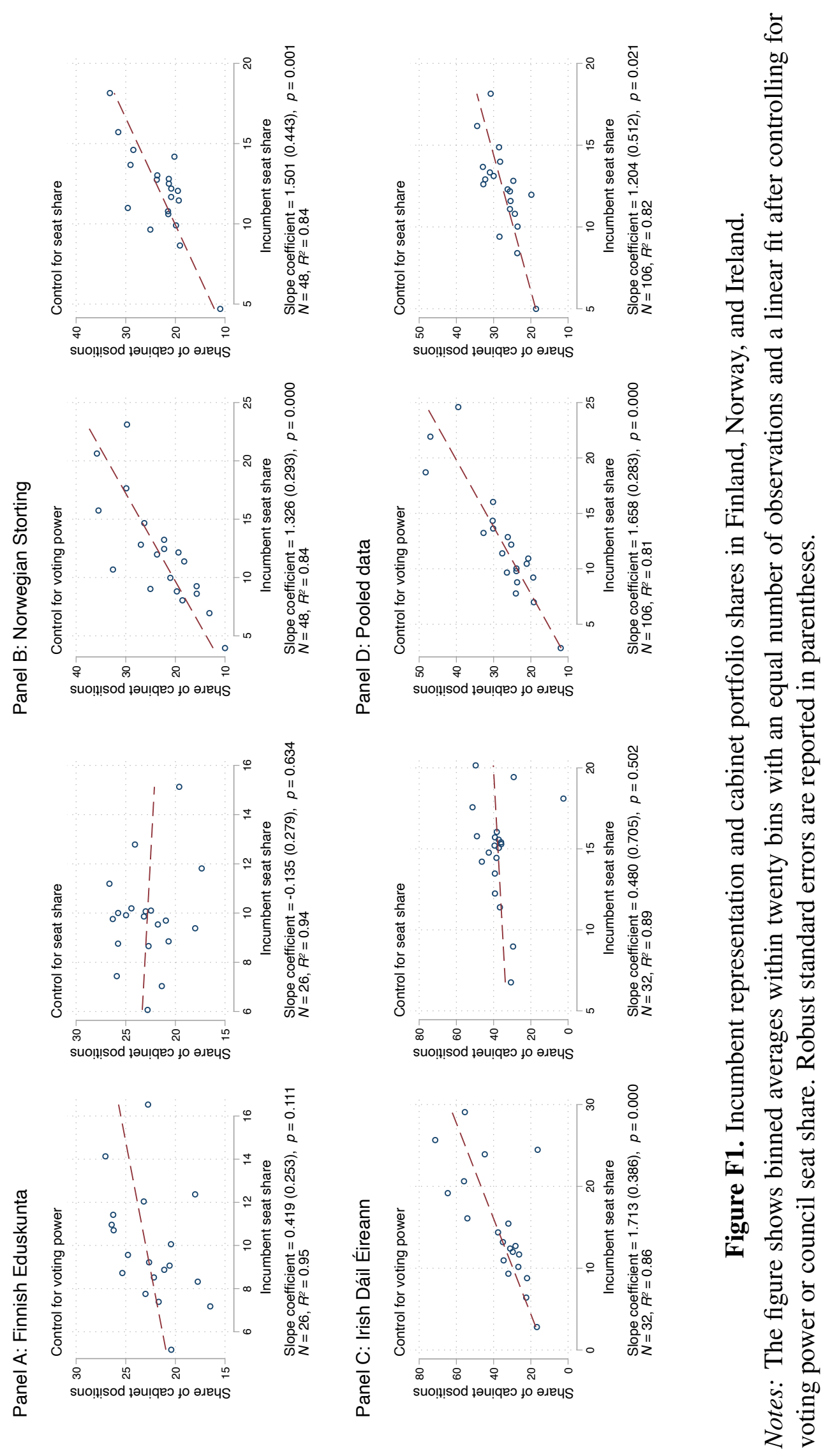


\section{References}

Ansolabehere, Stephen, James M. Snyder, and Charles Stewart. 2001. "Candidate Positioning in U.S. House Elections.” American Journal of Political Science 45 (1): 136-159.

Calonico, Sebastian, Matias D. Cattaneo, and Max H. Farrell. 2020. "Optimal bandwidth choice for robust bias-corrected inference in regression discontinuity designs." Econometrics Journal 23 (2): 192-210.

Cox, Gary W., Jon H. Fiva, Daniel M. Smith, and Rune J. Sørensen. 2021. "Moral Hazard in Electoral Teams." Working paper. Available online at https://www.jon.fiva.no/docs/ CoxFivaSmithSorensen2021.pdf.

De Magalhães, Leandro, Dominik Hangartner, Salomo Hirvonen, Jaakko Meriläinen, Nelson Ruiz, and Janne Tukiainen. 2020. "How Much Should We Trust Regression Discontinuity Design Estimates? Evidence from Experimental Benchmarks of the Incumbency Advantage." Working paper. Available online at https://preprints.apsanet.org/engage/apsa/ article-details/5f1a03d613857400119c3b13.

Fiva, Jon H., and Daniel M. Smith. 2017. "Norwegian parliamentary elections, 1906-2013: representation and turnout across four electoral systems." West European Politics 40 (6): $1373-1391$.

Heckman, James J., and James M. Snyder. 1997. "Linear Probability Models of the Demand for Attributes with an Empirical Application to Estimating the Preferences of Legislators." RAND Journal of Economics 28: 142-189.

Hyytinen, Ari, Jaakko Meriläinen, Tuukka Saarimaa, Otto Toivanen, and Janne Tukiainen. 2018. "When does regression discontinuity design work? Evidence from random election outcomes." Quantitative Economics 9 (2): 1019-1051.

McCrary, Justin. 2008. "Manipulation of the running variable in the regression discontinuity design: A density test." Journal of Econometrics 142 (2): 698-714.

Penrose, Lionel S. 1946. "The Elementary Statistics of Majority Voting." Journal of the Royal Statistical Society 109 (1): 53-57.

Shapley, Lloyd S., and Martin Shubik. 1954. "A Method for Evaluating the Distribution of Power in a Committee System.” American Political Science Review 48 (3): 787-792.

Smith, Daniel M., and Shane Martin. 2017. "Political Dynasties and the Selection of Cabinet Ministers." Legislative Studies Quarterly 42 (1): 131-165. 